\title{
Performance Evaluation of Iranian Electricity Distribution Units by Using Stochastic Data Envelopment Analysis
}

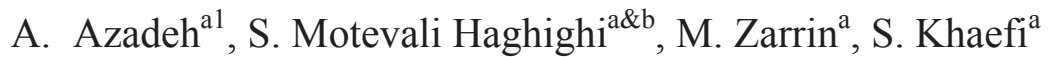 \\ ${ }^{a}$ School of Industrial Engineering, Center of Excellence for Intelligent-Based Experimental Mechanics, \\ College of Engineering, University of Tehran, Iran \\ ${ }^{b}$ Department of Industrial Engineering, Esfarayen University of Technology, Esfarayen, 9661998195, Iran
}

\begin{abstract}
This paper introduces an approach based on stochastic data envelopment analysis (SDEA) for performance assessment of electricity distribution units. A new approach is applied for assessment of Iranian distribution units from 2001 to 2011 in this paper. There are usually incomplete and stochastic data or lack of data with respect to electricity distribution companies. Due to lack of information about some parameters, theory of probability is imported to the model. Different Iranian distribution units are considered as decision making units (DMUs). Network length, transport capacity and the number of employees are chosen as inputs while number of customers and total electricity sales are chosen as stochastic outputs. Then, the best electricity distributions units are selected with respect to efficiency scores in stochastic environment. Also, SDEA model is performed for each input, separately to identify the most important input indicators by comparing the results of associated efficiencies with SDEA model. The empirical results show that network length is identified as the most important and influential

\footnotetext{
${ }^{1}$ Corresponding author: Tel: +98 2188021067; Fax: +98 2182084194.

E-mail address:aazadeh@ut.ac.ir
} 
input factor in this particular case study. To the best of our knowledge this is the first paper that examines stochastic outputs for assessment of electricity distribution units by SDEA in Iran.

Keywords: Electricity Distribution Units; Assessment; Performance Measures; Stochastic Data Envelopment Analysis; Network length

\section{Introduction}

Energy is one of the basic concerns after starting the industrial revolution. Therefore, improving the efficiency of electricity distributions is an important issue around the word. There are different parametric and non-parametric methods for estimating efficiency scores of electricity distribution units. Also, different indicators for measuring the efficiency of electricity distributions such as price or revenue cap regulation schemes, sliding-scale, rate of return, partial cost adjustment, menu of contracts, yardstick regulation, etc. are taken into account in previous studies such as Comnes et al. (1995), Hill (1995), Joskow and Schmalensee (1986), Jamasb and Pollitt (2001) and Hall (2000).

Electricity industry plays an important role in the development of the countries. Assessment of the electricity distribution industry plays an important role in improving the performance. Therefore, in this study, a new approach is applied for assessment of Iranian distribution units over the period 2001-2011 to improve the performance. In this regards, 17 Iranian electricity distribution units are considered as the decision making units in this study. The main objective of this study is assessment of electricity distribution units with respect to five important indicators, which considered by Omrani et al. (2010), including network length, transport capacity, number of employees, number of customers, and total electricity sales using SDEA approach. In addition, the most important input indicators are identified to enhance the performance of each electricity distribution unit. 
The rest of this paper is organized as follows. The relevant literature has been reviewed in Section 2. The proposed approach is presented in Section 3. The implementation procedure of the approach for evaluation the performance of electricity distribution units is investigated in Section 4 and the paper is concluded in Section 5.

\section{Literature Review}

In the last decade, assessment of the power sector performance has been gained increasing attentions. Policy making, performance optimization and assessment of electricity distribution units are very important issues for regulators in the electricity restructuring and reform. Indeed, the efficiency levels of various methodologies are employed to set $\mathrm{x}$-factors in the incentive regulation approaches such as revenue cap and price cap regulation. Debreu (1951) and Farrell (1957) introduced the concept of global technical efficiency and practical application of this theory had been established later in two category namely parametric and non-parametric approach. The parametric approaches apply statistical techniques whilst non-parametric approaches use linear and non-linear programming techniques such as data envelopment analysis (DEA) (Fallahi et al., 2011).

There are several studies about efficiency estimation electricity distribution units. Data envelopment analysis (DEA) is an ideal approach to evaluate the performance of various systems with multiple inputs and output. DEA is a popular optimization method for measuring the relative efficiency of decision making units (DMUs). Fallahi et al. (2011) used DEA approach to assess the performance of power electric generation management companies. They considered installed capacity, fuel, labor, electricity used, average operational, time, and net electricity 
produced as key performance indicators (KPIs). In addition, the efficient company was identified in their study.

Azadeh et al. (2009) presented a deterministic approach for performance assessment of electricity distribution units in Iran. They used DEA and principle component analysis (PCA) in their proposed approach. Network length, transformers capacity, number of employees, unit's delivery, and service area had been considered as major indicators in their study. In another study, Azadeh et al. (2009a) presented an approach based on DEA, corrected ordinary least squares (COLS), stochastic frontier analysis (SFA), and PCA methods for efficiency estimation of electricity distribution units. They selected the optimum DEA model for their particular case study. In addition, electricity distribution units had been evaluated and optimized through their proposed approach. They considered number of employees, operating costs, network length, transformer capacity, number of customers, size of service area, and unit's delivery as the most widely used indicators for evaluation of electricity distribution units.

DEA and window analysis (WA) were applied by Sözen et al. (2012) for efficiency assessment of ten hydro-power plants. They used DEA with respect to the production and energy unit cost in order to optimize hydro-power plants. See et al. (2012) presented SFA method for calculating technical efficiency levels of Malaysian thermal power plants. Fuel, labor, production indicator, and unit's delivery are chosen as input and output variables in their study. They demonstrated that plant size and fuel type have a significant impact on the performance.

An interactive robust data envelopment analysis (IRDEA) model was applied by Sadjadi et al. (2011) to determine the input and output target values of electricity distribution companies. In their study, network length, transport capacity, number of employees, number of customers, 
and total electricity sales are considered for assessment by IRDEA. Also, Omrani et al. (2010) considered these indicators to evaluate efficiency of Iranian electricity distribution units by using COLS and PCA. Lei and Feng (2012) and Amina, et al. (2012) presented forecasting problems in flied of with respect to price and consumption in power generation units.

In terms of the impact of the most important contextual variables on efficiency scores in electricity industries, Zhang and Bartels (1998) used DEA to study the effect of sample size on the mean productive efficiency of firms in electricity distribution in Australia, Sweden and New Zealand. By using Monte Carlo simulation, they showed that the mean efficiency is related to the sample size. Giannakis and Louis (2011) presented a quality-incorporated benchmarking study of the electricity distribution utilities in the UK between 1991/92 and 1998/99. They found that cost-efficient companies did not necessarily exhibit high service quality and that efficiency scores of cost-only models did not show high correlation with those of quality-based models. Their results showed that integrating quality of service in regulatory benchmarking is preferable to cost-only approaches.

Pacudan and De Guzman (2002) used DEA analyzed the productive efficiency and simulated the effect of the energy efficiency policy on the productive efficiency of the electricity distribution industry in the Philippines. They showed that the energy efficiency policy which benefits the overall economy and whole electricity supply industry results also in productive efficiency improvement in the distribution sector of the industry. Von Hirschhausen et al. (2006) applied non-parametric (DEA) and parametric tests to evaluate the efficiency of electricity distribution industries in Germany. In this study, the inputs include capital, labor, and peak load capacity, and units sold and the number of customers are output. The data cover 307 German 
electricity distribution industries. The results indicate that returns to scale play but a minor role; only very small utilities have a significant cost advantage.

In estimating efficiency measures of the electric distribution industry in the previous studies, the different variables as inputs and outputs are adopted. The inputs which are frequently used in these studies include: actual number of employees s (the number of employee); network losses (in GWh); and circuit km of network line (in kilometers) (Bagdadioglu et al., 1996; Pacudan and De Guzman, 2002). The number of employees represents labor input. Circuit km of network line and network loss denote capital inputs. Also the outputs variables include: actual number of customers (the number of customers); electricity sales (in GWh); and service area (in square kilometers). The number of customers shows the number of nodes the utility must supply. Many firms consist of geographically large distribution territories encompassing several cities, while others contain only a single city. The service area captures the effects of franchise area requirements and also consider the sparsely settled area. Both the $\mathrm{km} 2$ of service area and the number of customers denote customer density. It should be noted that electricity sales contain all power deliveries to final consumer units.

In this paper, due to the lack of information about some parameters a stochastic DEA model is applied for evaluation shaping factor for performance assessment of electricity distribution units with respect to five important indicators including network length, transport capacity, number of employees, the number of customers, and total electricity sales. These indicators are frequently applied for assessment of electricity distribution units (Jamasb and Pollitt, 2000). As mentioned before, network length, transport capacity, and the number of employees are controllable and deterministic indicators and are considered as inputs whilst 
number of customers and total electricity sales are uncontrollable and stochastic indicators and are chosen as outputs.

To the best of our knowledge, this is the first study that presents a novel approach for performance assessment of electricity distribution units with stochastic outputs. In addition, this study identifies important input indicators and weight of each input indicators have been achieved base on accurate mathematical modeling. The proposed approach is applied to Iranian distribution units from 2001 to 2011. The results of this approach can help managers and decision makers to improve the performance.

\subsection{Motivation and Significance}

There are usually incomplete and stochastic data or lack of data with respect to electricity distribution units. This means data could not be analyzed by the deterministic models. Therefore, due to lack of information about some parameters, theory of probability should be imported to previous models. In this regard, new approaches for tackling such stochastic problems are required. This gap motivated the authors to develop a unique approach to handle such gaps for evaluating stochastic environment. Moreover, SDEA is developed and applied for evaluation of electricity distribution units.

In addition, five important indicators including network length, transport capacity, number of employees, number of customers, and total electricity sales are considered in this study to evaluate different electricity distribution units. Network length, transport capacity, and the number of employees are controllable and deterministic indicators and are considered as inputs. In other hand, the number of customers and total electricity sales are uncontrollable and stochastic indicators and are chosen as outputs. It is therefore quite essential to identify 
influential controllable indicators. Decision makers can improve performance by focusing on these important indicators. This paper identifies important controllable indicators for assessment of electricity distribution units. Also, weights of each controllable indicators are calculated through an accurate mathematical model whilst these weight are obtained based on expert opinions in previous studies. To the best of our knowledge, this is the first study that presents a novel approach for evaluation electricity distribution units with stochastic indicators and identification of the most important input indicators.

\section{Methodology}

In this paper a stochastic DEA approach is used to evaluate electricity distribution units. Then, the most important input indicators are identified. SDEA is utilized to rank different electricity distribution units with respect to a set of key performance indicators in order to determine the optimum performance and identify the most important input indicators. Figure 1 presents a schematic view of the proposed approach in this study. In summary, the proposed approach is achieved as follows:

Step1: Collect the required data for electricity distribution units. The required data is collected from 2001 up to 2011 from publications of Iran Power Generation, Transmission and Distribution Management Company.

Step2: Define inputs and outputs of SDEA model. Outputs of this model are considered stochastic. Network length, transformers capacity and number of employees are chosen as inputs whilst number of customers and total electricity sales are chosen as stochastic outputs. 
Step 3: Define mean and standard deviation of each output indicator. The mean of each indicator during the 2001 to 2011 is considered as the value of each indicator. For output indicators, the standard deviation of each outputs is computed beads on data from 2001 to 2011.

Step 4: Apply SDEA model for evaluating electricity distribution units.

Step 5: Select the best $\alpha$ for SDEA model through noise analysis.

Step 6: Validate and verify the results of DEA model through statistical experiment.

Step 7: Perform sensitivity analysis. To this end, apply SDEA model by omitting input indicators one by one, separately.

Step 8: Identify the most important input indicators by comparing the results of the sensitivity analysis.

Step 9: Compute weight of each factor based on results of sensitivity analysis. 


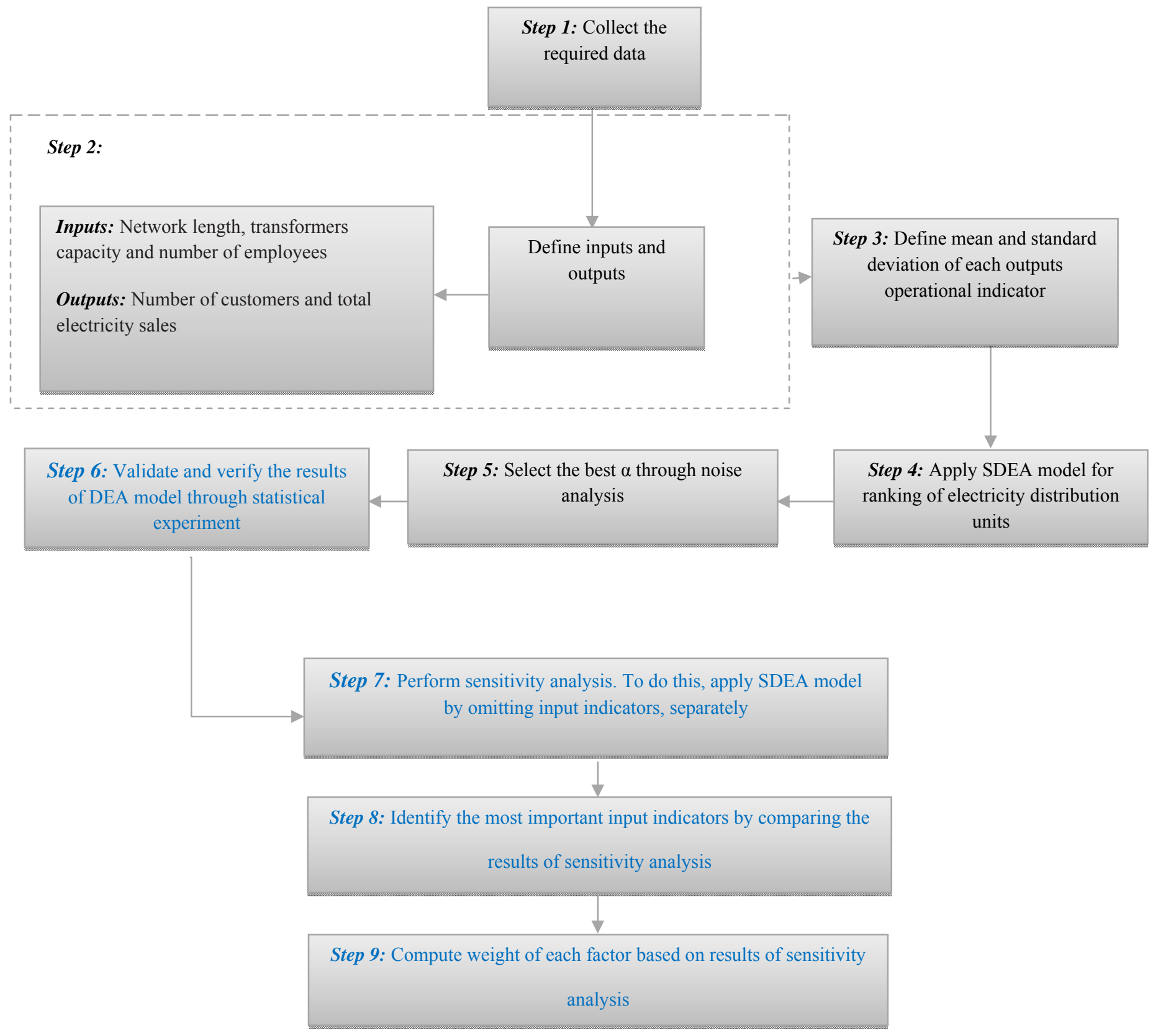

Figure 1: Schematic view of the proposed approach for evaluation of electricity distribution units

\subsection{Data Collection}

One of the important steps in the proposed algorithm is data collection. The results are not reliable, if this data are not collected correctly. In this paper, data is obtained from Iran Power Generation, Transmission and Distribution Management Company publications. As stated 
before, network length, transformers capacity and number of employee are considered as inputs variables and number of customers and total electricity sales are considered as outputs variables. These variables are frequently used in previous studies such as Omrani et al. (2010). Output indicators are considered as stochastic data set. In addition, for performing SDEA model, mean and standard deviation of the outputs variables are calculated.

\subsection{Stochastic DEA}

Data envelopment analysis (DEA) is an ideal approach to evaluate the performance of various systems with multiple inputs and output. DEA is a widely used optimization method for measuring the relative efficiency of decision making units (DMUs). This method is valuable decision support tool for calculating efficiency and evaluation of different systems (Omrani et al., 2010; Sengupta, 1987). In addition, efficient and inefficient units have been recognized by applying this approach (Charnes et al., 1978) and decision makers can improve the weaknesses of their organizations. This approach can apply multiple input and output indicators to compute efficiency scores, simultaneously (Serrano Cinca et al., 2006). DEA approach is a familiar deterministic approach for performance assessment but there are usually incomplete and stochastic data or lack of data with respect to electricity distribution units. This means data could not be collected and analyzed by deterministic models. To deal with this problem, stochastic model has been used in this study.

Sengupta (1987) introduced DEA model in stochastic case study. SDEA model deals with stochastic inputs and outputs. Stochastic data variations in indicators can be imported into the DEA model and provide a more accurate model for assessment of stochastic environments (Sengupta, 1987). Therefore, SDEA is a proper decisional approach to assessment different 
decision making units in stochastic environment whilst basic DEA model only works with certain indicators. In addition, basic DEA model is not accurate when faces with risk (Sueyoshi, 2000; $\mathrm{Wu}$ and Lee, 2010). The main advantage of SDEA is an accurate prediction in future decisions (Mirbolouki et al., 2013).

Sueyoshi (2000) introduced a CCR stochastic model that can be used for future planning. His proposed model can handle stochastic outputs and creates accurate results when there is incomplete information. Indeed, manager can control inputs of their organization whilst they are unable to control outputs because outputs are affected by external factors (Sueyoshi, 2000). Model (1) shows stochastic CCR which introduced by Sueyoshi (2000).

$$
\operatorname{Max} \sum_{r=1}^{s} u_{r} \bar{y}_{r k}
$$

s.t.

$\sum_{i=1}^{m} v_{i} x_{i k}=1$

$\sum_{i=1}^{m} v_{i}\left(\beta_{j} x_{i j}\right)-\sum_{r=1}^{s} u_{r}\left\{\bar{y}_{r j}+b_{r, j} F^{-1}\left(1-\alpha_{j}\right)\right\} \geq 0 \quad j=1, \ldots, n$

$u_{r}, v_{i} \geq 0$

The stochastic CCR Model (1) evaluates the relative efficiencies of n DMUs ( $\mathrm{j}=1 \ldots$ 17), each with $\mathrm{m}$ inputs and s outputs denoted by $x_{i j}$ and $y_{r j}$, respectively. In model (1), $u_{r}$ and $v_{i}$ are the factor weights. $b_{r, j}$ is standard deviation of $y_{r k}$ and $\bar{y}_{r k}$ is the mean of $y_{r k}$. Sueyoshi (2000) considered $\alpha_{j}$ as a risk criterion representing of decision makers and $\beta_{j}$ as an expected efficiency level of the $j$ th DMU (See Sueyoshi, 2000). Expected efficiency level for $j$ th DMU is equal to 1 in this particular case study. In addition, $\alpha_{j}$ demonstrates risk of environment. 
In this study, there are three inputs and two outputs. The network length, transformers capacity and the number of employees are considered as inputs. The number of customers and total electricity sales are considered as outputs. In addition, 17 different electricity units are considered as DMUs. The mean of each indicator during the 2001 to 2011 is considered as the value of each indicator. For output indicators, the standard deviation of each outputs is computed beads on data from 2001 to 2011.

\subsection{Noise Analysis}

For choosing the best $\alpha$ in SDEA model, noise analysis is performed for each $\alpha$ level. To do this, value of one indicator for one DMU is multiplied by 10, randomly. Then, SDEA model applied for different $\alpha$. This procedure is performed for 10 experiments. Finally, p-value of normality test is calculated for each experiment at different levels of $\alpha$. Model with the higher average p-value will be selected for evaluation performance assessment (Azadeh et al., 2013). In this study, this analysis is applied for selecting the best $\alpha$ parameters of SDEA model.

\subsection{Sensitivity Analysis}

As mentioned before, identifying the most influential input indicators for performance assessment is an important issue. This can help policy makers to have a more comprehensive and thorough understanding about indictors that have more effect on the system's performance. To do this, a sensitivity analysis has been performed. In this regard, SDEA model has been run three times for each input indicators, separately. In each run, the data set of one input must be eliminated. Then, correlation coefficient between results of SDEA after and before removing of each input are calculated. Low value for correlation shows the importance of omitted input. 
In Table 1, features of this approach are compared with the previous studies to show its advantages and superiorities.

Table 1: The proposed approach for assessment of electricity distribution units vs. other methods

\begin{tabular}{|c|c|c|c|c|c|c|c|c|c|}
\hline \multirow[b]{2}{*}{ Method } & \multicolumn{8}{|c|}{ Features } & \multirow[b]{2}{*}{$\begin{array}{c}\text { Practicability } \\
\text { in real world } \\
\text { cases }\end{array}$} \\
\hline & $\begin{array}{l}\text { Multiple } \\
\text { inputs } \\
\text { and } \\
\text { outputs }\end{array}$ & $\begin{array}{l}\text { Data } \\
\text { complexity } \\
\text { and non- } \\
\text { linearity }\end{array}$ & $\begin{array}{c}\text { Stochastic } \\
\text { Data }\end{array}$ & $\begin{array}{c}\text { Sensitivity } \\
\text { Analysis }\end{array}$ & $\begin{array}{l}\text { Data Pre- } \\
\text { processing } \\
\text { and post- } \\
\text { processing }\end{array}$ & Optimization & $\begin{array}{l}\text { Identification } \\
\text { of important } \\
\text { factors }\end{array}$ & $\begin{array}{c}\text { Calculated } \\
\text { weight factor } \\
\text { by } \\
\text { mathematical } \\
\text { modeling }\end{array}$ & \\
\hline $\begin{array}{c}\text { The } \\
\text { proposed } \\
\text { method }\end{array}$ & $\checkmark$ & $\checkmark$ & $\checkmark$ & $\checkmark$ & $\checkmark$ & $\checkmark$ & $\checkmark$ & $\checkmark$ & $\checkmark$ \\
\hline $\begin{array}{l}\text { Omrani et } \\
\text { al. (2010) }\end{array}$ & $\checkmark$ & $\checkmark$ & & & $\checkmark$ & $\checkmark$ & & & $\checkmark$ \\
\hline $\begin{array}{l}\text { Azadeh et } \\
\text { al. (2009) }\end{array}$ & $\checkmark$ & $\checkmark$ & & $\checkmark$ & $\checkmark$ & $\checkmark$ & & & $\checkmark$ \\
\hline $\begin{array}{c}\text { Sözen et al. } \\
\text { (2012) }\end{array}$ & $\checkmark$ & $\checkmark$ & & & $\checkmark$ & $\checkmark$ & & & $\checkmark$ \\
\hline $\begin{array}{l}\text { Sadjadi et } \\
\text { al. (2011) }\end{array}$ & $\checkmark$ & $\checkmark$ & $\checkmark$ & & $\checkmark$ & $\checkmark$ & & & $\checkmark$ \\
\hline
\end{tabular}

\section{Case Study}

In this section, Iranian electricity distribution units are considered as the experiment of this study. The proposed approach is applied to Iranian distribution units from 2001 to 2011 . In this study, 17 units of Iranian distribution units are considered as DMUs. The network length, transformers capacity and the number of employees are chosen as inputs while the number of customers and total electricity sales are chosen as stochastic outputs. As mentioned before, these variables are frequently used by previous studies such as (Omrani et al., 2010). The measurement units for the network length, transformers capacity and total electricity sales are kilometer $(\mathrm{km})$, MVA and MWh, respectively. Our data sets involve annual data on 17 units observed over the eleven-year period from 2001 to 2011. This data is obtained from Iran Power Generation, 
Transmission and Distribution Management Company publications. The number of customers and total electricity sales are not deterministic. Table 2 shows the raw data of Iranian electricity distribution units for 2001. Data for other years are shown in Tables 10 to 19 of Appendix I.

Table 2: Data for electricity distribution units (2001)

\begin{tabular}{|c|c|c|c|c|c|}
\hline 2001 & $\begin{array}{l}\text { Network } \\
\text { length }\end{array}$ & $\begin{array}{l}\text { Transport } \\
\text { capacity }\end{array}$ & $\begin{array}{l}\text { Number of } \\
\text { employees }\end{array}$ & $\begin{array}{l}\text { Number of } \\
\text { customer }\end{array}$ & Total electricity sales \\
\hline Esfahan & 37747.30 & 4100.60 & 4045.00 & 1408544.00 & 10899900.00 \\
\hline Azerbaijan & 50958.00 & 3524.00 & 4259.00 & 1737246.00 & 6055061.00 \\
\hline Bakhtar & 38389.74 & 3262.90 & 3319.00 & 1035574.00 & 7533912.00 \\
\hline Tehran & 47861.00 & 11166.00 & 8655.00 & 4040018.00 & 21339882.00 \\
\hline Khorasan & 51622.00 & 3714.00 & 4471.00 & 1638911.00 & 8018057.00 \\
\hline Zanjan & 18311.34 & 558.71 & 1150.00 & 476785.00 & 2968774.00 \\
\hline Semnan & 7354.12 & 680.30 & 608.00 & 170057.00 & 1433864.00 \\
\hline Systan - Baluchestan & 14309.67 & 951.66 & 1706.00 & 293300.00 & 1448853.00 \\
\hline Gharb & 27366.78 & 2148.70 & 1984.00 & 768800.00 & 2768793.00 \\
\hline Kerman & 25026.00 & 1449.00 & 2291.00 & 525678.00 & 4253445.00 \\
\hline Kish & 689.55 & 165.49 & 161.00 & 10309.00 & 201653.00 \\
\hline Gilan & 20288.60 & 1413.82 & 2149.00 & 678213.00 & 2339062.00 \\
\hline Mazandaran & 31341.19 & 2750.10 & 2444.00 & 1137302.00 & 4216201.00 \\
\hline Hormozgan & 14678.00 & 1591.00 & 2163.00 & 254376.00 & 3613971.00 \\
\hline Yazd & 9479.82 & 831.54 & 952.00 & 295591.00 & 2166935.00 \\
\hline Khuzestan 3 & 245080.00 & 5955.95 & 6481.00 & 788655.00 & 11286739.00 \\
\hline Fars1 & 39452.00 & 4142.00 & 3611.00 & 1086094.00 & 6625987.00 \\
\hline
\end{tabular}

\subsection{Inputs and Outputs of SDEA Model}

In this study, SDEA is applied for ranking DMUs with respect to five important indicators. These indicators are applied for assessment of electricity distribution units, frequently (Jamasb and Pollitt, 2000; Omrani et al., 2010). Network length, transport capacity and the number of employees are chosen as inputs while the number of customers and total electricity sales are chosen as stochastic outputs. Mean and standard derivation is calculated for stochastic indicators of each DMUs. Due to lack of information about some outputs variables, they are 
considered as stochastic data sets. The mean of each indicator during the 2001 to 2011 is considered as the value of each indicator. The standard deviation of each output is computed beads on data from 2001 to 2011. The results are shown in Tables 3 and 4 .

Table 3: Mean of indicators for each DMU

\begin{tabular}{|c|c|c|c|c|c|}
\hline Mean & $\begin{array}{c}\text { Network } \\
\text { length }\end{array}$ & Transport capacity & $\begin{array}{c}\text { Number of } \\
\text { employees }\end{array}$ & $\begin{array}{c}\text { Number of } \\
\text { customers }\end{array}$ & $\begin{array}{c}\text { Total electricity } \\
\text { sales }\end{array}$ \\
\hline Esfahan & 46639.12 & 5552.37 & 2178.27 & 673474.10 & 15761464.45 \\
\hline Azerbaijan & 58576.64 & 4532.87 & 3194.45 & 653070.27 & 7310036.09 \\
\hline Bakhtar & 43194.89 & 4334.48 & 1925.09 & 485824.99 & 10154339.73 \\
\hline Tehran & 60704.45 & 14747.38 & 7383.82 & 2025151.64 & 28827170.82 \\
\hline Khorasan & 63148.09 & 4888.59 & 2693.91 & 784804.04 & 12032029.82 \\
\hline Zanjan & 20870.94 & 2000.54 & 722.09 & 228229.30 & 4653825.73 \\
\hline Semnan & 8923.74 & 870.63 & 379.73 & 84128.50 & 1993341.55 \\
\hline Systan - Baluchestan & 21901.15 & 1449.53 & 1023.36 & 152518.19 & 2496980.27 \\
\hline Gharb & 32681.80 & 2642.64 & 1175.91 & 366351.99 & 4135314.18 \\
\hline Kerman & 36803.91 & 2915.09 & 1213.55 & 266953.91 & 6263096.72 \\
\hline Kish & 13072.28 & 1368.75 & 218.00 & 227644.00 & 943638.00 \\
\hline Gilan & 22705.96 & 1890.64 & 1100.73 & 409489.50 & 3503522.18 \\
\hline Mazandaran & 30523.20 & 4215.13 & 1522.82 & 438400.39 & 6012477.45 \\
\hline Hormozgan & 17843.09 & 2291.00 & 1107.00 & 113915.70 & 6025715.36 \\
\hline Yazd & 13533.07 & 7117.84 & 19727.73 & 130705.96 & 3348636.09 \\
\hline Khuzestan 3 & 53833.00 & 8117.88 & 2982.45 & 398050.68 & 16878761.09 \\
\hline Fars1 & 50858.91 & 6214.21 & 2023.64 & 527308.72 & 11033563.01 \\
\hline
\end{tabular}

Table 4: Standard deviation of indicators for each DMU

\begin{tabular}{|c|c|c|c|c|c|}
\hline Standard Deviation & $\begin{array}{c}\text { Network } \\
\text { length }\end{array}$ & Transport capacity & $\begin{array}{c}\text { Number of } \\
\text { employees }\end{array}$ & $\begin{array}{c}\text { Number of } \\
\text { customers }\end{array}$ & $\begin{array}{c}\text { Total electricity } \\
\text { sales }\end{array}$ \\
\hline Esfahan & - & - & - & 923307.32 & 3221180.48 \\
\hline Azerbaijan & - & - & - & 988360.68 & 2498110.22 \\
\hline Bakhtar & - & - & - & 662872.25 & 1870250.01 \\
\hline Tehran & - & - & - & 2736129.94 & 4234524.74 \\
\hline Khorasan & - & - & - & 1067783.54 & 2535521.37 \\
\hline Zanjan & - & - & - & 311546.77 & 1216274.74 \\
\hline Semnan & - & - & - & 114420.21 & 395995.60 \\
\hline Systan - Baluchestan & - & - & - & 224299.04 & 790050.46 \\
\hline Gharb & - & - & - & 500367.46 & 913768.67 \\
\hline
\end{tabular}


Table 4: Standard deviation of indicators for each DMU

\begin{tabular}{|c|c|c|c|c|c|}
\hline Standard Deviation & $\begin{array}{c}\text { Network } \\
\text { length }\end{array}$ & Transport capacity & $\begin{array}{c}\text { Number of } \\
\text { employees }\end{array}$ & $\begin{array}{c}\text { Number of } \\
\text { customers }\end{array}$ & $\begin{array}{c}\text { Total electricity } \\
\text { sales }\end{array}$ \\
\hline Kerman & - & - & - & 348064.72 & 1446953.42 \\
\hline Kish & - & - & - & 481231.09 & 1393309.97 \\
\hline Gilan & - & - & - & 635069.24 & 1605073.93 \\
\hline Mazandaran & - & - & - & 630442.39 & 1689707.03 \\
\hline Hormozgan & - & - & - & 153876.97 & 1595633.68 \\
\hline Yazd & - & - & - & 547736.16 & 4264519.80 \\
\hline Khuzestan 3 & - & - & - & 735396.90 & 2966711.63 \\
\hline Fars1 & - & - & & & \\
\hline
\end{tabular}

\subsection{Results of SDEA Model}

SDEA models at different levels of $\alpha$ are performed for assessment of electricity units in this study. The efficiency scores for each unit at different levels of $\alpha$ are shown in Table 5.

Table 5: Efficiency results for SDEA

\begin{tabular}{|c|c|c|c|c|c|c|c|c|}
\hline \multirow{2}{*}{ Efficiency } & \multicolumn{9}{|c|}{$\boldsymbol{\alpha}$} \\
\cline { 2 - 8 } & $\mathbf{0 . 0 5}$ & $\mathbf{0 . 1}$ & $\mathbf{0 . 2}$ & $\mathbf{0 . 3}$ & $\mathbf{0 . 4}$ & $\mathbf{0 . 5}$ & $\mathbf{0 . 6}$ & $\mathbf{0 . 7}$ \\
\hline Esfahan & 0.749 & 0.749 & 0.853 & 0.903 & 0.951 & 1 & 1.391 & 3.551 \\
\hline Azerbaijan & 0.425 & 0.462 & 0.498 & 0.555 & 0.631 & 0.756 & 1.235 & 3.126 \\
\hline Bakhtar & 0.618 & 0.618 & 0.704 & 0.763 & 0.785 & 0.854 & 1.129 & 2.918 \\
\hline Tehran & 0.689 & 0.689 & 0.816 & 0.88 & 0.94 & 1 & 2.643 & 3.424 \\
\hline Khorasan & 0.651 & 0.796 & 0.74 & 0.783 & 0.867 & 1 & 1.323 & 3.484 \\
\hline Zanjan & 0.647 & 0.647 & 0.753 & 0.805 & 0.847 & 0.91 & 1.281 & 3.512 \\
\hline Semnan & 0.604 & 0.604 & 0.688 & 0.729 & 0.787 & 0.807 & 1.019 & 2.545 \\
\hline Systan - Baluchistan & 0.454 & 0.454 & 0.518 & 0.548 & 0.595 & 0.683 & 0.881 & 2.283 \\
\hline Gharb & 0.413 & 0.413 & 0.482 & 0.537 & 0.627 & 0.789 & 1.222 & 3.517 \\
\hline Kerman & 0.567 & 0.567 & 0.646 & 0.684 & 0.72 & 0.757 & 0.989 & 2.472 \\
\hline Kish & 0.347 & 0.347 & 0.446 & 0.559 & 0.707 & 1 & 2.15 & 11.604 \\
\hline Gilan & 0.497 & 0.497 & 0.611 & 0.694 & 0.809 & 1 & 2.3 & 4.764 \\
\hline Mazandaran & 0.418 & 0.418 & 0.478 & 0.529 & 0.607 & 0.746 & 1.181 & 3.334 \\
\hline Hormozgan & 0.697 & 0.697 & 0.818 & 0.868 & 0.915 & 1 & 1.051 & 1.242 \\
\hline Yazd & 0.35 & 0.35 & 0.408 & 0.439 & 0.471 & 0.504 & 0.538 & 0.991 \\
\hline Khuzestan 3 & 0.707 & 0.707 & 0.825 & 0.883 & 0.94 & 1 & 1.124 & 1.633 \\
\hline
\end{tabular}


Table 5: Efficiency results for SDEA

\begin{tabular}{|c|c|c|c|c|c|c|c|c|}
\hline \multirow{2}{*}{ Efficiency } & \multicolumn{9}{|c|}{$\boldsymbol{\alpha}$} \\
\cline { 2 - 10 } & $\mathbf{0 . 0 5}$ & $\mathbf{0 . 1}$ & $\mathbf{0 . 2}$ & $\mathbf{0 . 3}$ & $\mathbf{0 . 4}$ & $\mathbf{0 . 5}$ & $\mathbf{0 . 6}$ & $\mathbf{0 . 7}$ \\
\hline Fars1 & 0.537 & 0.537 & 0.634 & 0.681 & 0.716 & 0.766 & 1.046 & 2.944 \\
\hline
\end{tabular}

For selection the best $\alpha_{j}$ for this particular case study, $\alpha_{j}=0.1,0.2,0.3,0.4,0.5,0.6$, and 0.7 are considered. The results of SDEA for $\alpha=0.5$ are shown in Tables 6 . To select the best $\alpha_{j}$, noise analysis, which introduced in previous sections, is performed for each $\alpha_{j}$. The results of other noise analysis are shown in Tables 20 to 26 of Appendix II.

Table 6: Efficiency results for SDEA with noisy data $(\alpha=0.0 .5)$

\begin{tabular}{|c|c|c|c|c|c|c|c|c|c|c|}
\hline$\alpha=0.05$ & 1 & 2 & 3 & 4 & 5 & 6 & 7 & 8 & 9 & 10 \\
\hline Esfahan & 0.749 & 0.749 & 0.749 & 0.749 & 0.749 & 0.749 & 0.749 & 0.749 & 0.749 & 0.749 \\
\hline Azarbayejan & 0.444 & 0.251 & 0.425 & 0.425 & 0.425 & 0.425 & 0.425 & 0.425 & 0.425 & 0.462 \\
\hline Bakhtar & 0.646 & 0.618 & 0.538 & 0.618 & 0.618 & 0.618 & 0.618 & 0.618 & 0.618 & 0.618 \\
\hline Tehran & 0.689 & 0.689 & 0.689 & 0.689 & 0.689 & 0.689 & 0.689 & 0.689 & 0.689 & 0.689 \\
\hline Khorasan & 0.665 & 0.651 & 0.651 & 0.743 & 0.651 & 0.651 & 0.649 & 0.651 & 0.651 & 0.796 \\
\hline Zanjan & 0.7 & 0.647 & 0.647 & 0.647 & 0.647 & 0.647 & 0.647 & 0.647 & 0.647 & 0.647 \\
\hline Semnan & 0.636 & 0.604 & 0.604 & 0.604 & 0.528 & 0.604 & 0.604 & 0.604 & 0.604 & 0.604 \\
\hline $\begin{array}{c}\text { Systan - } \\
\text { Baluchistan } \\
\end{array}$ & 0.464 & 0.454 & 0.454 & 0.454 & 0.454 & 0.253 & 0.454 & 0.454 & 0.454 & 0.454 \\
\hline Gharb & 0.443 & 0.413 & 0.413 & 0.413 & 0.413 & 0.413 & 0.334 & 0.413 & 0.413 & 0.413 \\
\hline Kerman & 0.661 & 0.567 & 0.567 & 0.567 & 0.567 & 0.567 & 0.567 & 0.476 & 0.567 & 0.567 \\
\hline Kish & 0.292 & 0.347 & 0.347 & 0.347 & 0.347 & 0.347 & 0.347 & 0.347 & 0.347 & 0.347 \\
\hline Gilan & 0.522 & 0.497 & 0.497 & 0.497 & 0.497 & 0.497 & 0.497 & 0.497 & 0.497 & 0.497 \\
\hline Mazandaran & 0.472 & 0.418 & 0.418 & 0.418 & 0.418 & 0.418 & 0.418 & 0.418 & 0.418 & 0.418 \\
\hline Hormozgan & 0.697 & 0.697 & 0.697 & 0.697 & 0.697 & 0.697 & 0.697 & 0.697 & 0.697 & 0.697 \\
\hline Yazd & 0.35 & 0.35 & 0.35 & 0.35 & 0.35 & 0.35 & 0.35 & 0.35 & 0.35 & 0.35 \\
\hline Khuzestan 3 & 0.707 & 0.707 & 0.707 & 0.707 & 0.707 & 0.707 & 0.707 & 0.707 & 0.707 & 0.707 \\
\hline Fars1 & 0.582 & 0.537 & 0.537 & 0.537 & 0.537 & 0.537 & 0.537 & 0.537 & 0.537 & 0.537 \\
\hline
\end{tabular}

To select the optimum $\alpha, 10$ experiments are performed for each $\alpha$ level. In each experiment one indicators for one DMU is multiplied by 10 , randomly. Then, normality test is performed on efficacy score with noisy data by MINITAB $^{\circledR}$ and the best $\alpha$ is selected based on maximum average p-value. Table 7 shows $p$-value of normality test for different $\alpha$. 
Table 7: P-value for normality test

\begin{tabular}{|c|c|c|c|c|c|c|c|c|c|c|c|}
\hline$\alpha$ & 1 & 2 & 3 & 4 & 5 & 6 & 7 & 8 & 9 & 10 & Average \\
\hline 0.05 & 0.07 & 0.455 & 0.459 & 0.322 & 0.416 & 0.345 & 0.311 & 0.239 & 0.328 & 0.681 & 0.3626 \\
\hline 0.1 & 0.081 & 0.262 & 0.497 & 0.699 & 0.339 & 0.455 & 0.465 & 0.348 & 0.341 & 0.344 & 0.3831 \\
\hline 0.2 & 0.124 & 0.22 & 0.29 & 0.238 & 0.174 & 0.279 & 0.277 & 0.349 & 0.295 & 0.277 & 0.2523 \\
\hline 0.3 & 0.05 & 0.223 & 0.274 & 0.188 & 0.129 & 0.236 & 0.255 & 0.416 & 0.312 & 0.277 & 0.236 \\
\hline 0.4 & 0.117 & 0.471 & 0.515 & 0.739 & 0.35 & 0.57 & 0.518 & 0.375 & 0.533 & 0.259 & $\mathbf{0 . 4 4 4 7}$ \\
\hline 0.5 & $<0.005$ & $<0.005$ & $<0.005$ & 0.008 & $<0.005$ & 0.009 & 0.006 & 0.017 & 0.012 & $<0.005$ & 0.0077 \\
\hline 0.6 & $<0.005$ & $<0.005$ & $<0.005$ & $<0.005$ & $<0.005$ & $<0.005$ & $<0.005$ & $<0.005$ & $<0.005$ & $<0.005$ & $<0.005$ \\
\hline 0.7 & $<0.005$ & $<0.005$ & $<0.005$ & $<0.005$ & $<0.005$ & $<0.005$ & $<0.005$ & $<0.005$ & $<0.005$ & $<0.005$ & $<0.005$ \\
\hline
\end{tabular}

According to Table 7 , for $\alpha=0.4$, average of $p$-value is higher than other $\alpha$. So, this $\alpha$ must be selected for SDEA model. As seen in Table 5, Esfahan has the best performance at $\alpha=0.4$. This unit can be selected as benchmarked unit for future decisions and planning.

\subsection{Validation and Verification}

The proposed model must be validated and verified by other models. In this study, SDEA model under deterministic condition is compared with deterministic DEA to demonstrate its acceptable performance. To this end, stochastic and deterministic DEA are compared for validation and verification. In SDEA model, if $b_{r j}=0$ and the value of output equals to mean the result of SDEA and deterministic DEA must be similar. Table 8 shows deterministic CCR and stochastic CCR under this condition.

Table 8: Compare deterministic and stochastic (when $b_{r j}=0$ )

\begin{tabular}{|c|c|c|}
\hline Efficiency & $\begin{array}{c}\text { Deterministic } \\
\text { output-oriented CCR }\end{array}$ & $\begin{array}{c}\text { Stochastic } \\
\text { output-oriented CCR }\end{array}$ \\
\hline Esfahan & 1 & 1 \\
\hline Azarbayejan & 0.756 & 0.756 \\
\hline Bakhtar & 0.854 & 0.854 \\
\hline
\end{tabular}


Table 8: Compare deterministic and stochastic (when $b_{r j}=0$ )

\begin{tabular}{|c|c|c|}
\hline Efficiency & Deterministic & Stochastic \\
\hline Tehran & 1 & 1 \\
\hline Khorasan & 1 & 1 \\
\hline Zanjan & 0.91 & 0.91 \\
\hline Semnan & 0.807 & 0.807 \\
\hline Systan - Baluchistan & 0.683 & 0.683 \\
\hline Gharb & 0.789 & 0.789 \\
\hline Kerman & 0.757 & 0.757 \\
\hline Kish & 1 & 1 \\
\hline Gilan & 1 & 1 \\
\hline Mazandaran & 0.746 & 0.746 \\
\hline Hormozgan & 1 & 1 \\
\hline Yazd & 0.504 & 0.504 \\
\hline Khuzestan 3 & 1 & 0.766 \\
\hline Fars1 & 0.766 & \\
\hline
\end{tabular}

According to Table 8 these two models have same results. Correlation analysis was performed for the result of these models by MINITAB ${ }^{\circledR}$. Moreover, Pearson correlation is equal to one. Thus, the SDEA is validated and verified by deterministic DEA under above condition.

\subsection{Importance of Input Indicators}

As mentioned before, manager can control inputs of their organization whilst they are unable to control outputs because outputs are affected by external factors. In addition, managers can improve performance of their organizations by controlling of inputs. Therefore, identification of important indicators can help decision makers to enhance their performance. To select the most important input indicators, SDEA model is performed three times for each input. Table 9 shows the results of the sensitivity analysis. Also, correlation coefficients between results of SDEA after and before the sensitivity analysis for each removed inputs are shown in Table 9. 
Table 9: Efficiency results for SDEA model at $\alpha=0.4$

\begin{tabular}{|c|c|c|c|}
\hline \multirow{2}{*}{ DMU } & \multicolumn{3}{|c|}{ Removed input } \\
\cline { 2 - 4 } & Network length & $\begin{array}{c}\text { Transport } \\
\text { capacity }\end{array}$ & $\begin{array}{c}\text { Number of } \\
\text { employees }\end{array}$ \\
\hline Esfahan & 0.646 & 0.951 & 0.951 \\
\hline Azarbayejan & 0.253 & 0.631 & 0.314 \\
\hline Bakhtar & 0.453 & 0.785 & 0.693 \\
\hline Tehran & 0.94 & 0.704 & 0.523 \\
\hline Khorasan & 0.375 & 0.867 & 0.595 \\
\hline Zanjan & 0.43 & 0.779 & 0.847 \\
\hline Semnan & 0.427 & 0.767 & 0.69 \\
\hline Systan - Baluchistan & 0.223 & 0.595 & 0.323 \\
\hline Gharb & 0.256 & 0.611 & 0.483 \\
\hline Kerman & 0.325 & 0.72 & 0.678 \\
\hline Kish & 0.389 & 0.638 & 0.707 \\
\hline Gilan & 0.403 & 0.809 & 0.452 \\
\hline Mazandaran & 0.391 & 0.52 & 0.531 \\
\hline Hormozgan & 0.635 & 0.881 & 0.715 \\
\hline Yazd & 0.471 & 0.158 & 0.022 \\
\hline Khuzestan 3 & 0.94 & 0.696 & 0.744 \\
\hline Fars1 & 0.418 & 0.595 & 0.716 \\
\hline Correlation with SDEA & $\mathbf{0 . 6 9 3}$ & $\mathbf{0 . 8 3 1}$ & $\mathbf{0 . 7 4 1}$ \\
\hline
\end{tabular}

According to Table 9, elimination of network length has the greatest effect on the SDEA's results. Therefore, this input indicator is identified as the most important indicator in this particular case study through the proposed approach. Mangers and decision makers can enhance performance of each electricity units by focusing on this important input indicators.

\subsection{Weights of Input Indicators}

Weight of each input indicators is calculated based on results of sensitivity analysis. In this regard, the percentage difference between correlation values for each removed input and 1 shows the weight of each input. Figure 2 shows these weights for this particular case study. 


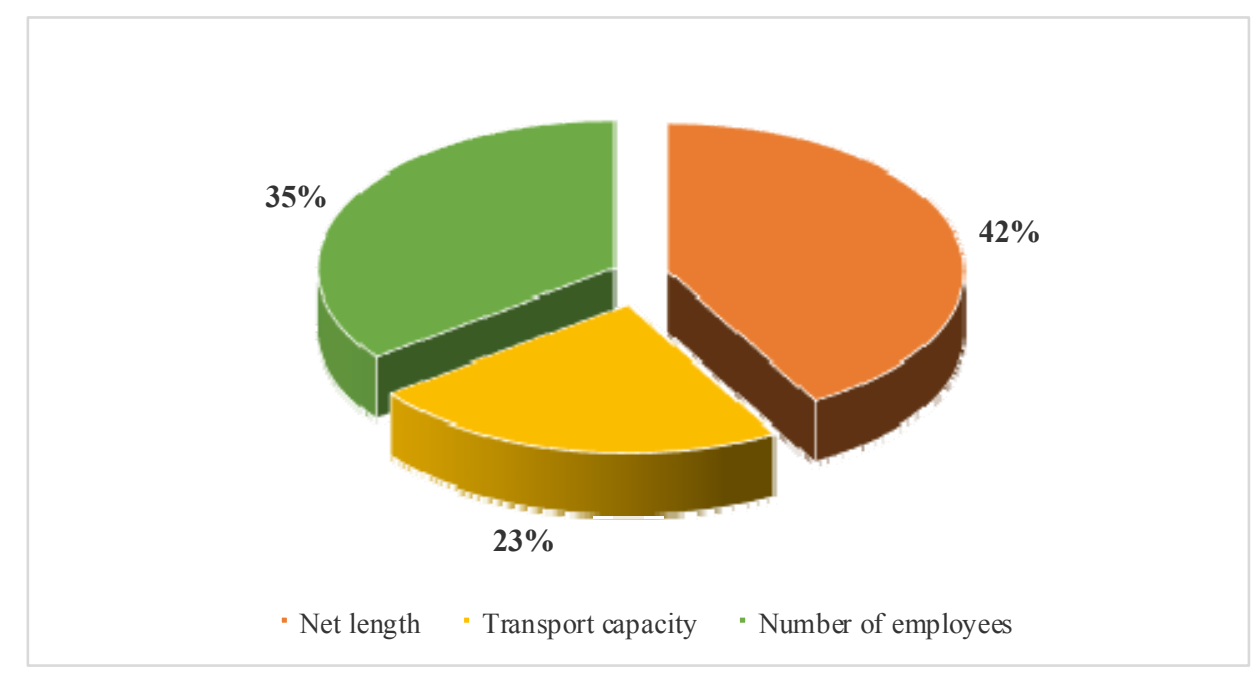

Figure 2: Weight of each input indicators in this particular case study

Referring to Figure 2, network length and the number of employees compose about $77 \%$ of total weights. Weight of network length is $42 \%$, which shows the importance of this inputs for this case study.

\section{Conclusion}

In this paper, a stochastic data envelopment analysis (SDEA) was applied for assessment of electricity distribution units. This approach was used for evaluating different electricity distribution unit in Iran. The importance degree of each input indicator was identified through the proposed approach. There are usually incomplete and stochastic data or lack of data with respect to electricity distribution companies. Therefore, due to lack of information about some parameters, SDEA was applied for this study. Five important indicators including network length, transport capacity, the number of employees, the number of customers, and total electricity sales were considered to evaluate the performance of electricity distribution units. 
Network length, transport capacity, and the number of employees were controllable and deterministic indicators and were considered as inputs and the number of customers and total electricity sales were uncontrollable and stochastic indicators and were considered as outputs. To identify the best SDEA model, the noise analysis was performed to select the best level of $\alpha$ for SDEA model. The results of selected SDEA showed that Esfehan has the best performance among electricity distribution units. This unit can be selected as benchmarked unit for future decisions and planning.

Identifying influential input indicators for performance assessment is an important issue.

This is very helpful for managers to have a more comprehensive and thorough understanding about indictors that have more effect on system's performance. To do this, a sensitivity analysis was performed to identify these important indicators. The sensitivity results demonstrated that network length and the number of employees were the most important input indicators for this particular case study. In addition, the weight of network length indicator was 0.42 , which showed importance of this input indicator in forming performance efficiency. Mangers and decision makers can enhance performance of each electricity units by focusing on this important input indicators. To the best of our knowledge, this is the first study that presents a novel approach for performance assessment of electricity distribution units with stochastic outputs and identify the most important factor through accurate mathematical modelling.

\section{Acknowledgment}

The authors are grateful for the valuable comments and suggestions from the respected reviewers. Their valuable comments and suggestions have enhanced the strength and significance of our paper. 


\section{References}

Amina, M., Kodogiannis, V. S., Petrounias, I., \& Tomtsis, D. (2012). A hybrid intelligent approach for the prediction of electricity consumption. International Journal of Electrical Power \& Energy Systems, 43(1), 99-108.

Azadeh, A., Ghaderi, S. F., \& Omrani, H. (2009). A deterministic approach for performance assessment and optimization of power distribution units in Iran. Energy Policy, 37(1), 274-280.

Azadeh, A., Ghaderi, S. F., Omrani, H., \& Eivazy, H. (2009a). An integrated DEA-COLS-SFA algorithm for optimization and policy making of electricity distribution units. Energy Policy, 37(7), 2605-2618.

Azadeh, A., Saberi, M., Rouzbahman, M., Saberi, Z. (2013a). An intelligent algorithm for performance evaluation of job stress and HSE factors in petrochemical plants with noise and uncertainty. Journal of Loss Prevention in the Process Industries 26(1), 140-152.

Bagdadioglu, N., Price, C. M. W., and Weyman-Jones, T. G. (1996). Efficiency and ownership in electricity distribution: a non-parametric model of the Turkish experience: Energy Economics, 18(1), 1-23.

Charnes, A., Cooper, W. W., \& Rhodes, E. (1978). Measuring the efficiency of decision making units. European journal of operational research, 2(6), 429-444.

Debreu, G. (1951). The coefficient of resource utilization. Econometrica: Journal of the Econometric Society, 273-292.

Fallahi, A., Ebrahimi, R., \& Ghaderi, S. F. (2011). Measuring efficiency and productivity change in power electric generation management companies by using data envelopment analysis: A case study. Energy, 36(11), 6398-6405. 
Farrell, M. J. (1957). The measurement of productive efficiency. Journal of the Royal Statistical Society. Series A (General), 253-290.

Giannakis, M., and Louis, M. (2011). A multi-agent based framework for supply chain risk management: Journal of Purchasing and Supply Management, 17(1), 23-31.

Hall, G. L. (2000). Electricity pricing and regulatory practice in a competitive environmentWorkshop Paper No. 2: Analysis of alternative ratemaking methodologies. Manila. Prepared by Hagler Bailly Services, Inc. for the Asian Development Bank and Philippines Energy Regulatory Board.

Hill, L. J. (1995). A primer on incentive regulation for electric utilities (No. ORNL/CON--422). Oak Ridge National Lab., TN (United States).

Jamasb, T., \& Pollitt, M. (2000). Benchmarking and regulation: international electricity experience. Utilities Policy, 9(3), 107-130.

Joskow, P. L., \& Schmalensee, R. (1986). Incentive regulation for electric utilities. Yale J. on Reg., 4, 1 .

Lei, M., \& Feng, Z. (2012). A proposed grey model for short-term electricity price forecasting in competitive power markets. International Journal of Electrical Power \& Energy Systems, 43(1), 531-538.

Mirbolouki, M., Behzadi, M. H., \& Korzaledin, M. (2013). Multiplier Models in Stochastic DEA.

Omrani, H., Azadeh, A., Ghaderi, S. F., \& Aabdollahzadeh, S. (2010). A consistent approach for performance measurement of electricity distribution companies. International Journal of Energy Sector Management, 4(3), 399-416. 
Pacudan, R., and De Guzman, E. (2002). Impact of energy efficiency policy to productive efficiency of electricity distribution industry in the Philippines: Energy Economics, 24(1), 41-54.

Sadjadi, S. J., Omrani, H., Makui, A., \& Shahanaghi, K. (2011). An interactive robust data envelopment analysis model for determining alternative targets in Iranian electricity distribution companies. Expert Systems with Applications, 38(8), 9830-9839.

See, K. F., \& Coelli, T. (2012). An analysis of factors that influence the technical efficiency of Malaysian thermal power plants. Energy Economics, 34(3), 677-685.

Sözen, A., Alp, İ., \& Kilinc, C. (2012). Efficiency assessment of the hydro-power plants in Turkey by using Data Envelopment Analysis. Renewable Energy, 46, 192-202.

Sueyoshi, T. (2000). Stochastic DEA for restructure strategy: an application to a Japanese petroleum company. Omega, 28(4), 385-398.

Von Hirschhausen, C., Cullmann, A., and Kappeler, A. (2006). Efficiency analysis of German electricity distribution utilities-non-parametric and parametric tests: Applied Economics, $38(21), 2553-2566$.

Wang, J., Ma, X., Wu, J., \& Dong, Y. (2012). Optimization models based on GM (1, 1) and seasonal fluctuation for electricity demand forecasting. International Journal of Electrical Power \& Energy Systems, 43(1), 109-117.

Zhang, Y., and Bartels, R. (1998). The effect of sample size on the mean efficiency in DEA with an application to electricity distribution in Australia, Sweden and New Zealand: Journal of Productivity Analysis, 9(3), 187-204. 


\section{Appendix I: Raw Data}

Table 10: Data for electricity distribution units (2002)

\begin{tabular}{|c|c|c|c|c|c|}
\hline 2002 & $\begin{array}{c}\text { Network } \\
\text { length }\end{array}$ & $\begin{array}{l}\text { Transport } \\
\text { capacity }\end{array}$ & No. of employees & $\begin{array}{l}\text { No. of } \\
\text { customer }\end{array}$ & Total electricity sales \\
\hline Esfahan & 39634.00 & 4315.00 & 3984.00 & 1459338.00 & 11652381.00 \\
\hline Azerbaijan & 53845.00 & 3678.00 & 4270.00 & 1809458.00 & 6385003.00 \\
\hline Bakhtar & 37838.00 & 3416.00 & 3247.00 & 1072062.00 & 8048383.00 \\
\hline Tehran & 54014.00 & 12412.00 & 8540.00 & 4334127.00 & 23083551.00 \\
\hline Khorasan & 52345.00 & 3886.00 & 4561.00 & 1683766.00 & 8868613.00 \\
\hline Zanjan & 18713.00 & 1661.00 & 1186.00 & 497281.00 & 3198700.00 \\
\hline Semnan & 7607.00 & 699.00 & 612.00 & 179057.00 & 1534797.00 \\
\hline Systan - Baluchestan & 15685.00 & 1006.00 & 1951.00 & 308580.00 & 1565183.00 \\
\hline Gharb & 28305.00 & 755.00 & 1960.00 & 803127.00 & 2996889.00 \\
\hline Kerman & 27752.00 & 1808.00 & 2164.00 & 556997.00 & 4285029.00 \\
\hline Kish & - & - & 156.00 & 11828.00 & 221022.00 \\
\hline Gilan & 20710.00 & 1461.00 & 2086.00 & 712964.00 & 2459212.00 \\
\hline Mazandaran & 32589.00 & 2950.00 & 2409.00 & 1198865.00 & 4446624.00 \\
\hline Hormozgan & 15834.00 & 1691.00 & 2169.00 & 269164.00 & 4242107.00 \\
\hline Yazd & 9970.00 & 870.00 & 1002.00 & 326279.00 & 2497046.00 \\
\hline Khuzestan 3 & 28408.00 & 6410.00 & 6253.00 & 818771.00 & 12135834.00 \\
\hline Fars1 & 43409.00 & 4305.00 & 3491.00 & 1129456.00 & 7455615.00 \\
\hline
\end{tabular}

Table 11: Data for electricity distribution units (2003)

\begin{tabular}{|c|c|c|c|c|c|}
\hline 2003 & $\begin{array}{c}\text { Network } \\
\text { length }\end{array}$ & $\begin{array}{l}\text { Transport } \\
\text { capacity }\end{array}$ & No. of employees & $\begin{array}{l}\text { No. of } \\
\text { customer }\end{array}$ & Total electricity sales \\
\hline Esfahan & 41473.00 & 4555.00 & 1974.00 & 1519.94 & 12738011.00 \\
\hline Azerbaijan & 55509.00 & 3844.00 & 2911.00 & 1880.81 & 6793703.00 \\
\hline Bakhtar & 38923.00 & 3596.00 & 1789.00 & 1114.04 & 8514841.00 \\
\hline Tehran & 52726.00 & 11897.00 & 30433.00 & 4571.71 & 25609592.00 \\
\hline Khorasan & 57281.00 & 4098.00 & 2313.00 & 1779.16 & 9404952.00 \\
\hline Zanjan & 19114.00 & 1734.00 & 653.00 & 519.32 & 3442033.00 \\
\hline Semnan & 8064.00 & 730.00 & 374.00 & 186.78 & 1594953.00 \\
\hline Systan - Baluchestan & 17779.00 & 1048.00 & 798.00 & 330.67 & 1695564.00 \\
\hline Gharb & 29356.00 & 2383.00 & 1230.00 & 831.19 & 3258737.00 \\
\hline Kerman & 30225.00 & 2040.00 & 1084.00 & 577.18 & 4823673.00 \\
\hline Kish & - & - & - & - & - \\
\hline Gilan & 21186.00 & 1534.00 & 938.00 & 742.00 & 2600089.00 \\
\hline
\end{tabular}




\begin{tabular}{|c|c|c|c|c|c|}
\hline Mazandaran & 34124.00 & 3181.00 & 1474.00 & 1261.15 & 4778711.00 \\
\hline Hormozgan & 16185.00 & 1786.00 & 938.00 & 288.54 & 4742554.00 \\
\hline Yazd & 11990.00 & 963.00 & 576.00 & 340.53 & 2669038.00 \\
\hline Khuzestan 3 & 29646.00 & 6684.00 & 2414.00 & 859.32 & 13303894.00 \\
\hline Fars1 & 44928.00 & 4624.00 & 1995.00 & 1192.42 & 8396673.00 \\
\hline
\end{tabular}

Table 12: Data for electricity distribution units (2004)

\begin{tabular}{|c|c|c|c|c|c|}
\hline 2004 & $\begin{array}{c}\text { Network } \\
\text { length }\end{array}$ & $\begin{array}{l}\text { Transport } \\
\text { capacity }\end{array}$ & No. of employees & $\begin{array}{l}\text { No. of } \\
\text { customer }\end{array}$ & Total electricity sales \\
\hline Esfahan & 42972.00 & 4805.00 & 1893.00 & 1586.30 & 13798449.00 \\
\hline Azerbaijan & 56951.00 & 4011.00 & 2795.00 & 1927.87 & 7228854.00 \\
\hline Bakhtar & 40877.00 & 3855.00 & 1724.00 & 1172.43 & 9007012.00 \\
\hline Tehran & 54987.00 & 12537.00 & 4041.00 & 4810.44 & 27292588.00 \\
\hline Khorasan & 58845.00 & 4301.00 & 2191.00 & 1838.12 & 10535190.00 \\
\hline Zanjan & 19598.00 & 1812.00 & 636.00 & 541.78 & 3957009.00 \\
\hline Semnan & 8363.00 & 768.00 & 360.00 & 196.94 & 1777262.00 \\
\hline Systan - Baluchestan & 19922.00 & 1131.00 & 797.00 & 352.24 & 1928811.00 \\
\hline Gharb & 30437.00 & 2432.00 & 1146.00 & 859.65 & 3545622.00 \\
\hline Kerman & 31554.00 & 2145.00 & 997.00 & 598.65 & 5855387.00 \\
\hline Kish & - & - & - & - & - \\
\hline Gilan & 21665.00 & 1634.00 & 900.00 & 777.33 & 2668952.00 \\
\hline Mazandaran & 35619.00 & 3527.00 & 1449.00 & 1332.07 & 5295520.00 \\
\hline Hormozgan & 16510.00 & 1865.00 & 924.00 & 304.90 & 5502997.00 \\
\hline Yazd & 12595.00 & 1022.00 & 596.00 & 355.34 & 2909305.00 \\
\hline Khuzestan 3 & 30730.00 & 6949.00 & 2235.00 & 886.85 & 13928906.00 \\
\hline Fars1 & 46737.00 & 5141.00 & 1830.00 & 1251.02 & 8969383.00 \\
\hline
\end{tabular}

Table 13: Data for electricity distribution units (2005)

\begin{tabular}{|c|c|c|c|c|c|}
\hline $\mathbf{2 0 0 5}$ & $\begin{array}{c}\text { Network } \\
\text { length }\end{array}$ & $\begin{array}{c}\text { Transport } \\
\text { capacity }\end{array}$ & No. of employees & $\begin{array}{c}\text { No. of } \\
\text { customer }\end{array}$ & Total electricity sales \\
\hline Esfahan & 44467.00 & 5103.00 & 1756.00 & 1662.06 & 15030781.00 \\
\hline Azerbaijan & 55334.00 & 4110.00 & 2699.00 & 2003.57 & 7896263.00 \\
\hline Bakhtar & 42060.00 & 4087.00 & 1615.00 & 1216.55 & 9311046.00 \\
\hline Tehran & 58223.00 & 13243.00 & 3806.00 & 5019.69 & 28147247.00 \\
\hline Khorasan & 60754.00 & 4517.00 & 2173.00 & 1919.97 & 11672591.00 \\
\hline Zanjan & 20185.00 & 1913.00 & 622.00 & 561.13 & 3983770.00 \\
\hline Semnan & 8646.00 & 784.00 & 342.00 & 205.13 & 1846006.00 \\
\hline Systan - Baluchestan & 22968.00 & 1365.00 & 876.00 & 374.75 & 2151337.00 \\
\hline Gharb & 31772.00 & 2550.00 & 1053.00 & 905.22 & 3864628.00 \\
\hline
\end{tabular}




\begin{tabular}{|c|c|c|c|c|c|}
\hline Kerman & 37328.00 & 2609.00 & 948.00 & 622.92 & 5915235.00 \\
\hline Kish & & & & & \\
\hline Gilan & 22181.00 & 1746.00 & 750.00 & 811.19 & 2895883.00 \\
\hline Mazandaran & 36992.00 & 3852.00 & 1360.00 & 1402.54 & 5771225.00 \\
\hline Hormozgan & 17082.00 & 1950.00 & 904.00 & 337.91 & 6031783.00 \\
\hline Yazd & 13022.00 & 1064.00 & 509.00 & 372.86 & 3274078.00 \\
\hline Khuzestan 3 & 32740.00 & 7479.00 & 2111.00 & 929.51 & 14722922.00 \\
\hline Fars1 & 48413.00 & 5436.00 & 1746.00 & 1307.60 & 10025277.00 \\
\hline
\end{tabular}

Table 14: Data for electricity distribution units (2006)

\begin{tabular}{|c|c|c|c|c|c|}
\hline 2006 & $\begin{array}{c}\text { Network } \\
\text { length }\end{array}$ & $\begin{array}{c}\text { Transport } \\
\text { capacity }\end{array}$ & No. of employees & $\begin{array}{c}\text { No. of } \\
\text { customer }\end{array}$ & Total electricity sales \\
\hline Esfahan & 46309.00 & 5413.00 & 1624.00 & 1745.80 & 15884273.00 \\
\hline Azerbaijan & 57210.00 & 4362.00 & 3158.00 & 2083.70 & 8766284.00 \\
\hline Bakhtar & 43155.00 & 4279.00 & 1544.00 & 1264.90 & 9785106.00 \\
\hline Tehran & 60415.00 & 13687.00 & 3587.00 & 5254.20 & 29710279.00 \\
\hline Khorasan & 65009.00 & 4866.00 & 2143.00 & 1999.20 & 12687079.00 \\
\hline Zanjan & 20770.00 & 2035.00 & 602.00 & 586.10 & 4627296.00 \\
\hline Semnan & 9049.00 & 843.00 & 317.00 & 213.70 & 1979703.00 \\
\hline Systan - Baluchestan & 24598.00 & 1524.00 & 835.00 & 467.40 & 2505986.00 \\
\hline Gharb & 32568.00 & 2659.00 & 897.00 & 952.80 & 4300071.00 \\
\hline Kerman & 39082.00 & 3083.00 & 923.00 & 646.30 & 6830984.00 \\
\hline \multicolumn{6}{|l|}{ Kish } \\
\hline Gilan & 22597.00 & 1840.00 & 718.00 & 841.00 & 3075617.00 \\
\hline Mazandaran & 38300.00 & 4139.00 & 1278.00 & 1482.50 & 6409714.00 \\
\hline Hormozgan & 17629.00 & 2063.00 & 866.00 & 340.40 & 6600621.00 \\
\hline Yazd & 13455.00 & 66011.00 & 477.00 & 387.80 & 3603417.00 \\
\hline Khuzestan 3 & 33853.00 & 7838.00 & 2105.00 & 975.80 & 16382160.00 \\
\hline Fars1 & 51205.00 & 6228.00 & 1644.00 & 1369.90 & 11084566.00 \\
\hline
\end{tabular}

Table 15: Data for electricity distribution units (2007)

\begin{tabular}{|c|c|c|c|c|c|}
\hline $\mathbf{2 0 0 7}$ & $\begin{array}{c}\text { Network } \\
\text { length }\end{array}$ & $\begin{array}{c}\text { Transport } \\
\text { capacity }\end{array}$ & No. of employees & $\begin{array}{c}\text { No. of } \\
\text { customer }\end{array}$ & Total electricity sales \\
\hline Esfahan & 48218 & 5689 & 1633 & 1835 & 16794850.00 \\
\hline Azerbaijan & 59719 & 4703 & 3112 & 2177 & 3101426.00 \\
\hline Bakhtar & 44147 & 4496 & 1528 & 1320 & 10487158.00 \\
\hline Tehran & 62218 & 15664 & 3794 & 5512 & 30966261.00 \\
\hline Khorasan & 66086 & 5096 & 2194 & 2096 & 12823747.00 \\
\hline Zanjan & 21411 & 2175 & 585 & 615 & 5729670.00 \\
\hline Semnan & 9245 & 905 & 307 & 225 & 2027008.00 \\
\hline
\end{tabular}




\begin{tabular}{|c|c|c|c|c|c|} 
Systan - Baluchestan & 26542 & 1606 & 821 & 425 & 2632679.00 \\
\hline Gharb & 33550 & 2820 & 830 & 980 & 4607076.00 \\
\hline Kerman & 40048 & 3293 & 922 & 673 & 6732974.00 \\
\hline Kish & - & - & - & - & - \\
\hline Gilan & 23076 & 1953 & 665 & 879 & 3284026.00 \\
\hline Mazandaran & 39452 & 4428 & 1222 & 1559 & 6739852.00 \\
\hline Hormozgan & 18018 & 2232 & 853 & 362 & 6648703.00 \\
\hline Yazd & 13922 & 1232 & 476 & 409 & 4014579.00 \\
\hline Khuzestan 3 & 35011 & 8275 & 2097 & 1019 & 17376412.00 \\
\hline Fars1 & 52211.00 & 6440.00 & 1487.00 & 1439.00 & 12042883.00 \\
\hline
\end{tabular}

Table 16: Data for electricity distribution units (2008)

\begin{tabular}{|c|c|c|c|c|c|}
\hline 2008 & $\begin{array}{c}\text { Network } \\
\text { length }\end{array}$ & $\begin{array}{c}\text { Transport } \\
\text { capacity }\end{array}$ & No. of employees & $\begin{array}{l}\text { No. of } \\
\text { customer }\end{array}$ & Total electricity sales \\
\hline Esfahan & 49846.00 & 6079.52 & 1494.00 & 1929.00 & 18158021.00 \\
\hline Azerbaijan & 61246.00 & 4979.62 & 2769.00 & 2309.00 & 9860557.00 \\
\hline Bakhtar & 45956.00 & 4811.38 & 1459.00 & 1389.00 & 11481777.00 \\
\hline Tehran & 66042.00 & 16725.19 & 3747.00 & 5666.00 & 30360639.00 \\
\hline Khorasan & 67739.00 & 5363.47 & 2067.00 & 2210.00 & 13718117.00 \\
\hline Zanjan & 22126.00 & 2325.20 & 537.00 & 649.00 & 5180132.00 \\
\hline Semnan & 9466.00 & 957.62 & 285.00 & 235.00 & 2302397.00 \\
\hline Systan - Baluchestan & 27420.00 & 1677.17 & 783.00 & 461.00 & 3432213.00 \\
\hline Gharb & 34706.00 & 3046.31 & 773.00 & 1029.00 & 4452746.00 \\
\hline Kerman & 41430.00 & 3594.00 & 867.00 & 721.00 & 6492820.00 \\
\hline Kish & - & - & - & - & 443611.00 \\
\hline Gilan & 23492.00 & 2056.25 & 612.00 & 923.00 & 3481712.00 \\
\hline Mazandaran & 40897.00 & 4838.35 & 1171.00 & 1644.00 & 7194672.00 \\
\hline Hormozgan & 18445.00 & 2411.00 & 824.00 & 381.00 & 7123016.00 \\
\hline Yazd & 14401.00 & 1236.72 & 401.00 & 433.00 & 4326187.00 \\
\hline Khuzestan 3 & 36279.00 & 8730.71 & 1962.00 & 1092.00 & 19871699.00 \\
\hline Fars 1 & 55335.00 & 6781.34 & 1346.00 & 1514.00 & 13177550.00 \\
\hline
\end{tabular}

Table 17: Data for electricity distribution units (2009)

\begin{tabular}{|c|c|c|c|c|c|}
\hline $\mathbf{2 0 0 9}$ & $\begin{array}{c}\text { Network } \\
\text { length }\end{array}$ & $\begin{array}{c}\text { Transport } \\
\text { capacity }\end{array}$ & No. of employees & $\begin{array}{c}\text { No. of } \\
\text { customer }\end{array}$ & $\begin{array}{c}\text { Total electricity } \\
\text { sales }\end{array}$ \\
\hline Esfahan & 51948.00 & 6514.00 & 1395.00 & 2039420.00 & 18481377.00 \\
\hline Azerbaijan & 63074.00 & 5265.00 & 2762.00 & 837465.00 & 10163640.00 \\
\hline Bakhtar & 46736.00 & 5243.00 & 1397.00 & 1464300.00 & 12054168.00 \\
\hline
\end{tabular}




\begin{tabular}{|c|c|c|c|c|c|}
\hline Tehran & 68607.00 & 17462.00 & 3753.00 & 6193313.00 & 32145292.00 \\
\hline Khorasan & 69772.00 & 5638.00 & 2010.00 & 2350013.00 & 14175449.00 \\
\hline Zanjan & 22636.00 & 2460.00 & 518.00 & 683545.00 & 5605774.00 \\
\hline Semnan & 9916.00 & 1016.00 & 283.00 & 248854.00 & 2364016.00 \\
\hline Systan - Baluchestan & 9916.00 & 1757.00 & 696.00 & 495437.00 & 3284082.00 \\
\hline Gharb & 36393.00 & 3235.00 & 757.00 & 1087511.00 & 5069514.00 \\
\hline Kerman & 43006.00 & 3821.00 & 838.00 & 770623.00 & 6794921.00 \\
\hline Kish & - & - & 0.00 & 23301.00 & 496890.00 \\
\hline Gilan & 24229.00 & 2194.00 & 650.00 & 970261.00 & 3616181.00 \\
\hline Mazandaran & -42352.00 & 5185.00 & 1251.00 & 1743528.00 & 7294597.00 \\
\hline Hormozgan & 19138.00 & 2653.00 & 764.00 & 417858.00 & 7834218.00 \\
\hline Yazd & 15997.00 & 1686.00 & 382.00 & 455316.00 & 4447248.00 \\
\hline Khuzestan 3 & 37980.00 & 9352.00 & 1913.00 & 1206176.00 & 20080773.00 \\
\hline Fars1 & 57247.00 & 7985.00 & 1296.00 & 1612796.00 & 13618811.00 \\
\hline
\end{tabular}

Table 18: Data for electricity distribution units (2010)

\begin{tabular}{|c|c|c|c|c|c|}
\hline 2010 & $\begin{array}{c}\text { Network } \\
\text { length }\end{array}$ & $\begin{array}{c}\text { Transport } \\
\text { capacity }\end{array}$ & No. of employees & $\begin{array}{c}\text { No. of } \\
\text { customer }\end{array}$ & Total electricity sales \\
\hline Esfahan & 54434.00 & 7009.00 & 2959.00 & 210992.00 & 19768506.93 \\
\hline Azerbaijan & 64582.00 & 5547.00 & 3977.00 & 55284.00 & 3560516.00 \\
\hline Bakhtar & 47986.00 & 5214.00 & 2456.00 & 151800.00 & 12755365.00 \\
\hline Tehran & 70350.00 & 18253.00 & 7277.00 & 920688.00 & 34515674.02 \\
\hline Khorasan & 71681.00 & 6004.00 & 3754.00 & 293742.00 & 15334828.00 \\
\hline Zanjan & 23132.00 & 2604.00 & 961.00 & 77612.00 & 6252663.00 \\
\hline Semnan & 10110.00 & 1061.00 & 451.00 & 35290.00 & 2522704.00 \\
\hline Systan - Baluchestan & 30644.00 & 1899.00 & 1247.00 & 1541.00 & 3352982.00 \\
\hline Gharb & 37175.00 & 3441.00 & 1567.00 & 121264.00 & 5355054.00 \\
\hline Kerman & 44092.00 & 4017.00 & 1498.00 & 198761.00 & 8190113.90 \\
\hline Kish & - & - & 170.00 & 4373.00 & 525000.00 \\
\hline Gilan & 24886.00 & 2393.00 & 1428.00 & 151800.00 & 4042980.00 \\
\hline Mazandaran & 43815.00 & 5584.00 & 2069.00 & 210992.00 & 4245620.00 \\
\hline Hormozgan & 20856.00 & 3315.00 & 1378.00 & 55284.00 & 8915764.00 \\
\hline Yazd & 16752.00 & 1763.00 & 864.00 & 62690.00 & 4760229.00 \\
\hline Khuzestan 3 & 40018.00 & 10394.00 & 3723.00 & 154990.00 & 23502415.00 \\
\hline Fars1 & 58941.00 & 8258.00 & 2539.00 & 121264.00 & 15041443.07 \\
\hline
\end{tabular}

Table 19: Data for electricity distribution units (2011)

\begin{tabular}{|c|c|c|c|c|c|}
\hline $\mathbf{2 0 1 1}$ & $\begin{array}{c}\text { Network } \\
\text { length }\end{array}$ & $\begin{array}{c}\text { Transport } \\
\text { capacity }\end{array}$ & No. of employees & $\begin{array}{c}\text { No. of } \\
\text { customer }\end{array}$ & Total electricity sales \\
\hline Esfahan & 55982.00 & 7493.00 & 1204.00 & 2279643.00 & 20169559.00 \\
\hline
\end{tabular}




\begin{tabular}{|c|c|c|c|c|c|}
\hline Azerbaijan & 65915.00 & 5838.00 & 2427.00 & 2731938.00 & 10599090.00 \\
\hline Bakhtar & 49076.00 & 5419.00 & 1098.00 & 1612862.00 & 12718969.00 \\
\hline Tehran & 72306.00 & 19175.00 & 3589.00 & 6757688.00 & 33927874.00 \\
\hline Khorasan & 73495.00 & 6291.00 & 1756.00 & 2654570.00 & 15113705.00 \\
\hline Zanjan & 23584.00 & 2728.00 & 493.00 & 771827.00 & 6246262.00 \\
\hline Semnan & 10341.00 & 1133.00 & 238.00 & 290893.00 & 2544047.00 \\
\hline Systan - Baluchestan & 31129.00 & 1980.00 & 747.00 & 576431.00 & 3469093.00 \\
\hline Gharb & 37871.00 & 3599.00 & 738.00 & 1243612.00 & 5269326.00 \\
\hline Kerman & 45300.00 & 4207.00 & 817.00 & 880595.00 & 8719482.00 \\
\hline Kish & 25455.00 & 2572.00 & 603.00 & 1088409.00 & 3773652.00 \\
\hline Gilan & 25455.00 & 2572.00 & 1212.00 & 1986173.00 & 8075030.00 \\
\hline Mazandaran & 44978.00 & 5932.00 & 624.00 & 523036.00 & 9744516.00 \\
\hline Hormozgan & 21899.00 & 3644.00 & 394.00 & 254376.00 & 5027135.00 \\
\hline Yazd & 17280.00 & 1617.00 & 210770.00 & 295591.00 & 2166935.00 \\
\hline Khuzestan 3 & 42418.00 & 11229.00 & 1513.00 & 1404203.00 & 23074618.00 \\
\hline Fars1 & 61570.00 & 9016.00 & 1275.00 & 1842712.00 & 14931005.00 \\
\hline
\end{tabular}

\section{Appendix II: Sensitivity Analysis Results}

Table 20: Efficiency results for SDEA with noisy data $(\alpha=0.1)$

\begin{tabular}{|c|c|c|c|c|c|c|c|c|c|c|}
\hline$\alpha=0.1$ & 1 & 2 & 3 & 4 & 5 & 6 & 7 & 8 & 9 & 10 \\
\hline Esfahan & 0.792 & 0.792 & 0.792 & 0.792 & 0.792 & 0.792 & 0.792 & 0.792 & 0.792 & 0.792 \\
\hline Azarbayejan & 0.483 & 0.695 & 0.451 & 0.451 & 0.451 & 0.451 & 0.451 & 0.451 & 0.451 & 0.451 \\
\hline Bakhtar & 0.691 & 0.654 & 0.572 & 0.654 & 0.654 & 0.654 & 0.654 & 0.654 & 0.654 & 0.654 \\
\hline Tehran & 0.741 & 0.741 & 0.741 & 0.842 & 0.741 & 0.741 & 0.741 & 0.741 & 0.741 & 0.741 \\
\hline Khorasan & 0.719 & 0.693 & 0.693 & 0.693 & 0.787 & 0.693 & 0.693 & 0.693 & 0.687 & 0.693 \\
\hline Zanjan & 0.749 & 0.691 & 0.691 & 0.691 & 0.691 & 0.658 & 0.691 & 0.691 & 0.691 & 0.691 \\
\hline Semnan & 0.681 & 0.639 & 0.639 & 0.639 & 0.639 & 0.639 & 0.564 & 0.639 & 0.639 & 0.639 \\
\hline $\begin{array}{c}\text { Systan - } \\
\text { Baluchistan }\end{array}$ & 0.501 & 0.481 & 0.481 & 0.481 & 0.481 & 0.481 & 0.481 & 0.267 & 0.481 & 0.481 \\
\hline Gharb & 0.481 & 0.437 & 0.437 & 0.437 & 0.437 & 0.437 & 0.437 & 0.437 & 0.363 & 0.437 \\
\hline Kerman & 0.652 & 0.6 & 0.6 & 0.6 & 0.6 & 0.6 & 0.6 & 0.6 & 0.6 & 0.52 \\
\hline Kish & 0.346 & 0.346 & 0.346 & 0.346 & 0.346 & 0.346 & 0.346 & 0.346 & 0.346 & 0.346 \\
\hline Gilan & 0.571 & 0.538 & 0.538 & 0.538 & 0.538 & 0.538 & 0.538 & 0.538 & 0.538 & 0.538 \\
\hline Mazandaran & 0.49 & 0.443 & 0.443 & 0.443 & 0.443 & 0.443 & 0.443 & 0.443 & 0.443 & 0.443 \\
\hline Hormozgan & 0.747 & 0.747 & 0.747 & 0.747 & 0.747 & 0.747 & 0.747 & 0.747 & 0.747 & 0.747 \\
\hline Yazd & 0.374 & 0.374 & 0.374 & 0.374 & 0.374 & 0.374 & 0.374 & 0.374 & 0.374 & 0.374 \\
\hline Khuzestan 3 & 0.755 & 0.755 & 0.755 & 0.755 & 0.755 & 0.755 & 0.755 & 0.755 & 0.755 & 0.755 \\
\hline Fars 1 & 0.638 & 0.576 & 0.576 & 0.576 & 0.576 & 0.576 & 0.576 & 0.576 & 0.576 & 0.576 \\
\hline
\end{tabular}


Table 21: Efficiency results for SDEA with noisy data $(\alpha=0.2)$

\begin{tabular}{|c|c|c|c|c|c|c|c|c|c|c|}
\hline$\alpha=0.2$ & 1 & 2 & 3 & 4 & 5 & 6 & 7 & 8 & 9 & 10 \\
\hline Esfahan & 0.853 & 0.853 & 0.853 & 0.853 & 0.853 & 0.853 & 0.853 & 0.853 & 0.853 & 0.853 \\
\hline Azarbayejan & 0.538 & 0.777 & 0.498 & 0.498 & 0.498 & 0.498 & 0.498 & 0.498 & 0.498 & 0.498 \\
\hline Bakhtar & 0.759 & 0.704 & 0.62 & 0.704 & 0.704 & 0.704 & 0.704 & 0.704 & 0.704 & 0.704 \\
\hline Tehran & 0.816 & 0.816 & 0.816 & 0.89 & 0.816 & 0.816 & 0.816 & 0.816 & 0.816 & 0.816 \\
\hline Khorasan & 0.797 & 0.747 & 0.747 & 0.747 & 0.849 & 0.747 & 0.747 & 0.747 & 0.74 & 0.747 \\
\hline Zanjan & 0.92 & 0.753 & 0.753 & 0.753 & 0.753 & 0.739 & 0.753 & 0.753 & 0.753 & 0.753 \\
\hline Semnan & 0.746 & 0.688 & 0.688 & 0.688 & 0.688 & 0.688 & 0.614 & 0.688 & 0.688 & 0.688 \\
\hline Systan - Baluchistan & 0.555 & 0.518 & 0.518 & 0.518 & 0.518 & 0.518 & 0.518 & 0.288 & 0.518 & 0.518 \\
\hline Gharb & 0.537 & 0.482 & 0.482 & 0.482 & 0.482 & 0.482 & 0.482 & 0.482 & 0.405 & 0.482 \\
\hline Kerman & 0.753 & 0.646 & 0.646 & 0.646 & 0.646 & 0.646 & 0.646 & 0.646 & 0.646 & 0.589 \\
\hline Kish & 0.446 & 0.446 & 0.446 & 0.446 & 0.446 & 0.446 & 0.446 & 0.446 & 0.446 & 0.446 \\
\hline Gilan & 0.642 & 0.611 & 0.611 & 0.611 & 0.611 & 0.611 & 0.611 & 0.611 & 0.611 & 0.611 \\
\hline Mazandaran & 0.545 & 0.478 & 0.478 & 0.478 & 0.478 & 0.478 & 0.478 & 0.478 & 0.478 & 0.478 \\
\hline Hormozgan & 0.818 & 0.818 & 0.818 & 0.818 & 0.818 & 0.818 & 0.818 & 0.818 & 0.818 & 0.818 \\
\hline Yazd & 0.409 & 0.408 & 0.408 & 0.408 & 0.408 & 0.408 & 0.408 & 0.408 & 0.408 & 0.408 \\
\hline Khuzestan 3 & 0.825 & 0.825 & 0.825 & 0.825 & 0.825 & 0.825 & 0.825 & 0.825 & 0.825 & 0.825 \\
\hline Fars1 & 0.712 & 0.634 & 0.634 & 0.762 & 0.634 & 0.634 & 0.634 & 0.634 & 0.634 & 0.634 \\
\hline
\end{tabular}

Table 22: Efficiency results for SDEA with noisy data $(\alpha=0.3)$

\begin{tabular}{|c|c|c|c|c|c|c|c|c|c|c|}
\hline$\alpha=0.3$ & 1 & 2 & 3 & 4 & 5 & 6 & 7 & 8 & 9 & 10 \\
\hline Esfahan & 0.903 & 0.903 & 0.903 & 0.903 & 0.903 & 0.903 & 0.903 & 0.903 & 0.903 & 0.903 \\
\hline Azarbayejan & 0.582 & 0.848 & 0.555 & 0.555 & 0.555 & 0.555 & 0.555 & 0.555 & 0.555 & 0.555 \\
\hline Bakhtar & 0.821 & 0.763 & 0.658 & 0.763 & 0.763 & 0.763 & 0.763 & 0.763 & 0.763 & 0.763 \\
\hline Tehran & 0.88 & 0.88 & 0.88 & 0.88 & 0.88 & 0.88 & 0.88 & 0.88 & 0.88 & 0.88 \\
\hline Khorasan & 0.862 & 0.784 & 0.784 & 0.783 & 0.901 & 0.784 & 0.784 & 0.784 & 0.783 & 0.784 \\
\hline Zanjan & 0.962 & 0.805 & 0.805 & 0.805 & 0.805 & 0.805 & 0.805 & 0.805 & 0.805 & 0.805 \\
\hline Semnan & 0.8 & 0.729 & 0.729 & 0.729 & 0.729 & 0.729 & 0.655 & 0.729 & 0.729 & 0.729 \\
\hline Systan - & 0.6 & 0.548 & 0.548 & 0.548 & 0.548 & 0.548 & 0.548 & 0.305 & 0.548 & 0.548 \\
\hline Baluchistan & 0.588 & 0.537 & 0.537 & 0.537 & 0.537 & 0.537 & 0.537 & 0.537 & 0.441 & 0.537 \\
\hline Gharb & 0.791 & 0.684 & 0.684 & 0.684 & 0.684 & 0.684 & 0.684 & 0.684 & 0.684 & 0.644 \\
\hline Kerman & 0.564 & 0.559 & 0.559 & 0.559 & 0.559 & 0.559 & 0.559 & 0.559 & 0.559 & 0.559 \\
\hline Kish & 0.717 & 0.694 & 0.694 & 0.694 & 0.694 & 0.694 & 0.694 & 0.694 & 0.694 & 0.694 \\
\hline Gilan & 0.608 & 0.529 & 0.529 & 0.546 & 0.529 & 0.529 & 0.529 & 0.529 & 0.529 & 0.529 \\
\hline Mazandaran & 0.878 & 0.868 & 0.868 & 0.868 & 0.868 & 0.868 & 0.868 & 0.868 & 0.868 & 0.868 \\
\hline Hormozgan & 0.44 & 0.439 & 0.439 & 0.456 & 0.439 & 0.439 & 0.439 & 0.439 & 0.439 & 0.439 \\
\hline Yazd & 0.883 & 0.883 & 0.883 & 0.883 & 0.883 & 0.883 & 0.883 & 0.883 & 0.883 & 0.883 \\
\hline Khuzestan 3 & 0.817 & 0.681 & 0.681 & 0.681 & 0.681 & 0.681 & 0.681 & 0.681 & 0.681 & 0.681 \\
\hline Fars1 & & & & & &
\end{tabular}


Table 23: Efficiency results for SDEA with noisy data $(\alpha=0.4)$

\begin{tabular}{|c|c|c|c|c|c|c|c|c|c|c|}
\hline$\alpha=0.4$ & 1 & 2 & 3 & 4 & 5 & 6 & 7 & 8 & 9 & 10 \\
\hline Esfahan & 0.951 & 0.951 & 0.951 & 0.951 & 0.951 & 0.951 & 0.951 & 0.951 & 0.951 & 0.951 \\
\hline Azarbayejan & 0.637 & 0.406 & 0.631 & 0.631 & 0.631 & 0.631 & 0.631 & 0.631 & 0.631 & 0.631 \\
\hline Bakhtar & 0.888 & 0.796 & 0.693 & 0.785 & 0.785 & 0.785 & 0.785 & 0.785 & 0.785 & 0.785 \\
\hline Tehran & 0.94 & 0.94 & 0.94 & 0.964 & 0.94 & 0.94 & 0.94 & 0.94 & 0.94 & 0.94 \\
\hline Khorasan & 0.927 & 0.867 & 0.867 & 0.867 & 0.949 & 0.867 & 0.867 & 0.867 & 0.867 & 0.867 \\
\hline Zanjan & 0.991 & 0.847 & 0.847 & 0.847 & 0.847 & 0.847 & 0.847 & 0.847 & 0.847 & 0.847 \\
\hline Semnan & 0.862 & 0.787 & 0.787 & 0.767 & 0.787 & 0.787 & 0.69 & 0.787 & 0.787 & 0.787 \\
\hline $\begin{array}{c}\text { Systan - } \\
\text { Baluchistan }\end{array}$ & 0.646 & 0.595 & 0.595 & 0.595 & 0.595 & 0.595 & 0.595 & 0.335 & 0.595 & 0.595 \\
\hline Gharb & 0.669 & 0.627 & 0.627 & 0.627 & 0.627 & 0.627 & 0.627 & 0.627 & 0.494 & 0.627 \\
\hline Kerman & 0.82 & 0.72 & 0.72 & 0.72 & 0.72 & 0.72 & 0.72 & 0.72 & 0.72 & 0.945 \\
\hline Kish & 0.715 & 0.707 & 0.707 & 0.707 & 0.707 & 0.707 & 0.707 & 0.707 & 0.707 & 0.707 \\
\hline Gilan & 0.819 & 0.809 & 0.809 & 0.809 & 0.809 & 0.809 & 0.809 & 0.809 & 0.809 & 0.809 \\
\hline Mazandaran & 0.687 & 0.607 & 0.607 & 0.665 & 0.607 & 0.607 & 0.607 & 0.607 & 0.607 & 0.607 \\
\hline Hormozgan & 0.937 & 0.915 & 0.915 & 0.915 & 0.915 & 0.915 & 0.915 & 0.915 & 0.915 & 0.915 \\
\hline Yazd & 0.471 & 0.471 & 0.471 & 0.541 & 0.471 & 0.471 & 0.471 & 0.471 & 0.471 & 0.471 \\
\hline Khuzestan 3 & 0.94 & 0.94 & 0.94 & 0.94 & 0.94 & 0.94 & 0.94 & 0.94 & 0.94 & 0.94 \\
\hline Fars1 & 0.815 & 0.717 & 0.717 & 0.717 & 0.717 & 0.716 & 0.717 & 0.717 & 0.717 & 0.717 \\
\hline
\end{tabular}

Table 24: Efficiency results for SDEA with noisy data $(\alpha=0.5)$

\begin{tabular}{|c|c|c|c|c|c|c|c|c|c|c|}
\hline$\alpha=0.5$ & 1 & 2 & 3 & 4 & 5 & 6 & 7 & 8 & 9 & 10 \\
\hline Esfahan & 1 & 1 & 1 & 1 & 1 & 1 & 1 & 1 & 1 & 1 \\
\hline Azarbayejan & 0.756 & 1 & 0.756 & 0.756 & 0.756 & 0.756 & 0.756 & 0.756 & 0.758 & 0.756 \\
\hline Bakhtar & 0.98 & 0.854 & 0.752 & 0.854 & 0.854 & 0.854 & 0.854 & 0.854 & 0.856 & 0.854 \\
\hline Tehran & 1 & 1 & 1 & 1 & 1 & 1 & 1 & 1 & 1 & 1 \\
\hline Khorasan & 1 & 1 & 1 & 1 & 1 & 1 & 1 & 0.91 & 0.91 & 0.91 \\
\hline Zanjan & 1 & 0.91 & 0.91 & 0.91 & 1 & 0.91 & 0.91 \\
\hline Semnan & 0.936 & 0.807 & 0.807 & 0.807 & 0.807 & 0.725 & 0.807 & 0.807 & 0.807 & 0.807 \\
\hline $\begin{array}{c}\text { Systan - } \\
\text { Baluchistan }\end{array}$ & 0.696 & 0.683 & 0.683 & 0.683 & 0.683 & 0.683 & 0.404 & 0.683 & 0.687 & 0.683 \\
\hline Gharb & 0.818 & 0.789 & 0.789 & 0.789 & 0.789 & 0.789 & 0.789 & 0.634 & 0.789 & 0.789 \\
\hline Kerman & 0.887 & 0.757 & 0.757 & 0.757 & 0.757 & 0.757 & 0.757 & 0.757 & 0.757 & 1 \\
\hline Kish & 1 & 1 & 1 & 1 & 1 & 1 & 1 & 1 \\
\hline Gilan & 1 & 1 & 1 & 1 & 1 & 1 & 1 & 1 \\
\hline
\end{tabular}




\begin{tabular}{|c|c|c|c|c|c|c|c|c|c|c|} 
Mazandaran & 0.812 & 0.746 & 0.746 & 0.864 & 0.746 & 0.746 & 0.746 & 0.746 & 0.746 & 0.746 \\
\hline Hormozgan & 1 & 1 & 1 & 1 & 1 & 1 & 1 & 1 & 1 & 1 \\
\hline Yazd & 0.504 & 0.505 & 0.505 & 0.678 & 0.505 & 0.505 & 0.505 & 0.505 & 0.505 & 0.505 \\
\hline Khuzestan 3 & 1 & 1 & 1 & 1 & 1 & 1 & 1 & 1 & 1 & 1 \\
\hline Fars1 & 0.889 & 0.766 & 0.766 & 0.766 & 0.766 & 0.766 & 0.766 & 0.766 & 0.766 & 0.766 \\
\hline
\end{tabular}

Table 25: Efficiency results for SDEA with noisy data $(\alpha=0.6)$

\begin{tabular}{|c|c|c|c|c|c|c|c|c|c|c|}
\hline$\alpha=0.6$ & 1 & 2 & 3 & 4 & 5 & 6 & 7 & 8 & 9 & 10 \\
\hline Esfahan & 1.358 & 1.391 & 1.391 & 1.437 & 1.391 & 1.391 & 1.391 & 1.391 & 1.391 & 1.391 \\
\hline Azarbayejan & 1.235 & 1.057 & 1.235 & 1.235 & 1.235 & 1.235 & 1.235 & 1.235 & 1.235 & 1.235 \\
\hline Bakhtar & 1.197 & 1.129 & 1.527 & 1.129 & 1.129 & 1.129 & 1.129 & 1.129 & 1.129 & 1.129 \\
\hline Tehran & 2.643 & 2.643 & 2.643 & 2.643 & 2.643 & 2.643 & 2.643 & 2.643 & 2.643 & 2.643 \\
\hline Khorasan & 1.339 & 1.323 & 1.323 & 1.323 & 1.525 & 1.323 & 1.323 & 1.323 & 1.323 & 1.323 \\
\hline Zanjan & 1.34 & 1.281 & 1.281 & 1.281 & 1.281 & 1.183 & 1.281 & 1.281 & 1.281 & 1.281 \\
\hline Semnan & 1.091 & 1.019 & 1.019 & 1.019 & 1.019 & 1.019 & 1.525 & 1.019 & 1.019 & 1.019 \\
\hline Systan - Baluchistan & 0.881 & 0.881 & 0.881 & 0.881 & 0.896 & 0.881 & 0.881 & 0.6 & 0.881 & 0.881 \\
\hline Gharb & 1.224 & 1.222 & 1.222 & 1.222 & 1.222 & 1.222 & 1.222 & 1.222 & 1.057 & 1.222 \\
\hline Kerman & 1.04 & 0.989 & 0.989 & 0.989 & 0.989 & 0.989 & 0.989 & 0.989 & 0.989 & 1.492 \\
\hline Kish & 2.15 & 2.15 & 2.15 & 2.15 & 2.15 & 2.15 & 2.15 & 2.15 & 2.15 & 2.15 \\
\hline Gilan & 2.3 & 2.3 & 2.3 & 2.3 & 2.3 & 2.3 & 2.3 & 2.3 & 2.3 & 2.3 \\
\hline Mazandaran & 1.181 & 1.181 & 1.181 & 1.323 & 1.181 & 1.181 & 1.181 & 1.181 & 1.181 & 1.181 \\
\hline Hormozgan & 1.109 & 1.018 & 1.051 & 1.051 & 1.018 & 1.051 & 1.018 & 1.051 & 1.018 & 1.018 \\
\hline Yazd & 0.538 & 0.538 & 0.539 & 0.967 & 0.538 & 0.539 & 0.538 & 0.54 & 0.538 & 0.538 \\
\hline Khuzestan 3 & 1.147 & 1.124 & 1.124 & 1.338 & 1.124 & 1.124 & 1.124 & 1.124 & 1.124 & 1.124 \\
\hline Fars1 & 1.132 & 1.046 & 1.046 & 1.087 & 1.046 & 1.046 & 1.046 & 1.046 & 1.046 & 1.046 \\
\hline
\end{tabular}


Table 26: Efficiency results for SDEA with noisy data $(\alpha=0.7)$

\begin{tabular}{|c|c|c|c|c|c|c|c|c|c|c|}
\hline$\alpha=0.7$ & 1 & 2 & 3 & 4 & 5 & 6 & 7 & 8 & 9 & 10 \\
\hline Esfahan & 3.551 & 3.551 & 3.551 & 3.551 & 3.551 & 3.551 & 3.551 & 3.551 & 3.551 & 3.551 \\
\hline Azarbayejan & 3.126 & 2.393 & 3.126 & 3.126 & 3.551 & 3.126 & 3.126 & 3.126 & 3.126 & 3.126 \\
\hline Bakhtar & 2.918 & 2.918 & 2.885 & 2.942 & 2.918 & 2.918 & 2.918 & 2.918 & 2.944 & 2.918 \\
\hline Tehran & 3.424 & 3.424 & 3.424 & 3.424 & 3.424 & 3.424 & 3.424 & 3.424 & 3.424 & 3.424 \\
\hline Khorasan & 3.484 & 3.484 & 3.484 & 3.484 & 3.316 & 3.484 & 3.484 & 3.484 & 3.484 & 3.484 \\
\hline Zanjan & 3.512 & 3.512 & 3.512 & 3.512 & 3.512 & 3.512 & 3.512 & 3.512 & 3.512 & 3.512 \\
\hline Semnan & 2.545 & 2.545 & 2.545 & 2.558 & 2.545 & 2.545 & 2.521 & 2.545 & 2.57 & 2.545 \\
\hline $\begin{array}{c}\text { Systan - } \\
\text { Baluchistan } \\
\end{array}$ & 2.283 & 2.283 & 2.283 & 2.283 & 2.593 & 2.283 & 2.283 & 1.712 & 2.283 & 2.283 \\
\hline Gharb & 3.517 & 3.517 & 3.517 & 3.517 & 3.517 & 3.517 & 3.517 & 3.517 & 3.517 & 3.517 \\
\hline Kerman & 2.472 & 2.472 & 2.472 & 2.472 & 2.472 & 2.483 & 2.472 & 2.472 & 2.513 & 3.157 \\
\hline Kish & 11.604 & 11.604 & 11.604 & 11.604 & 11.604 & 11.789 & 11.604 & 11.604 & 11.605 & 11.604 \\
\hline Gilan & 4.764 & 4.764 & 4.764 & 4.958 & 5.338 & 4.764 & 4.764 & 4.764 & 4.764 & 4.764 \\
\hline Mazandaran & 3.334 & 3.334 & 3.334 & 3.532 & 3.334 & 3.334 & 3.334 & 3.334 & 3.334 & 3.334 \\
\hline Hormozgan & 1.242 & 1.242 & 1.242 & 1.742 & 1.298 & 1.242 & 1.242 & 1.242 & 1.242 & 1.242 \\
\hline Yazd & 0.991 & 0.991 & 0.991 & 2.369 & 0.991 & 0.991 & 0.991 & 0.991 & 0.994 & 0.991 \\
\hline Khuzestan 3 & 1.633 & 1.783 & 1.633 & 2.896 & 1.633 & 1.633 & 1.633 & 1.633 & 1.633 & 1.633 \\
\hline Fars1 & 2.944 & 2.944 & 2.944 & 2.944 & 2.944 & 2.963 & 2.944 & 2.944 & 2.944 & 2.944 \\
\hline
\end{tabular}

